OSSANDÓN, Magdalena. "El legislador y el principio ne bis in idem".

Polít. crim. Vol. 13, No 26 (Diciembre 2018) Art. 8, pp. 952-1002.

[http://www.politicacriminal.cl/Vol_13/n_26/Vol13N26A8.pdf]

\title{
El legislador y el principio ne bis in idem*
}

\section{The legislator and the ne bis in idem principle}

\author{
María Magdalena Ossandón Widow \\ Doctora en Derecho, Universidad de Navarra \\ Profesora de Derecho penal, Pontificia Universidad Católica de Chile \\ mossandonw@uc.cl
}

\section{Resumen}

El artículo analiza el alcance del principio ne bis in idem respecto de la actividad legislativa. Tras sustentar su rango constitucional, se establece que este principio no excluye la posibilidad de que un mismo hecho esté tipificado y asociado a una sanción en más de un precepto. Reconocida la procedencia de una superposición de normas sancionatorias, se revisa a continuación si el ne bis in idem tiene alguna repercusión en el tratamiento de las hipótesis de concurso ideal de delitos y de concurso aparente de leyes penales. Después de constatar que restringir el ámbito de aplicación de este principio únicamente a la actuación judicial termina por hacerle desaparecer, se argumenta que el legislador se encuentra también obligado, en cierta medida, por el ne bis in idem al establecer sanciones penales o administrativas.

Palabras clave: ne bis in idem, concurso de delitos, principio de legalidad, proporcionalidad, derecho administrativo sancionatorio.

\begin{abstract}
This paper analyses the field of application of the ne bis in idem principle in legislative activity. After asserting its constitutional recognition, it is established that this principle does not exclude the possibility for one action to be typified and associated with a sanction in more than one rule. Once a superposition of sanctioning norms is recognized as legitimate, this article examines whether this principle has any repercussion in the treatment of the hypothesis of ideal concurrence of crimes and apparent concurrency of criminal laws. After verifying that restricting the scope of application of the ne bis in idem only to judicial action will make this principle disappear, it is argued that the legislator is also bound, to some extent, by the ne bis in idem when establishing criminal or administrative sanctions.
\end{abstract}

Key words: ne bis in idem, concurrence offences, principle of legality, proportionality, Punitive Administrative Law

\footnotetext{
* Trabajo redactado en el marco del proyecto de investigación Fondecyt N N 1140998 "El principio ne bis in idem y sus implicaciones para la actividad legislativa penal".
} 
OSSANDÓN, Magdalena. "El legislador y el principio ne bis in idem".

\section{Introducción}

En relación con el ne bis in idem, como advierte buena parte de la doctrina, el acuerdo "se reduce de modo tautológico a un par de certezas plenamente defendibles: nadie debe ser perseguido o castigado dos veces por lo mismo"1.

En este sentido, existe consenso en orden a que este principio involucra una doble prohibición: a) una prohibición material que alude a que un mismo hecho no debe ser objeto de doble sanción, o más precisamente, que una misma circunstancia o aspecto no debe ser objeto de una doble ponderación (no debe ser valorado dos veces); y b) una prohibición procesal, que impide someter a alguien a un juzgamiento simultáneo o sucesivo a otro que recae sobre el mismo hecho ${ }^{2}$.

Tradicionalmente se entiende también que la concurrencia de "lo mismo" presupone que se aprecie identidad de sujeto, hecho y fundamento, es decir, un mismo contenido de injusto.

En general, el ne bis in idem es considerado una garantía propia de todo ordenamiento penal democrático que sea respetuoso de la dignidad personal y de los derechos que emanan de la naturaleza humana ${ }^{3}$; y ha sido incluido en forma expresa en diversos instrumentos internacionales sobre Derechos Humanos, precisamente porque se estima que esta prohibición constituye una de las exigencias mínimas de respeto a la persona en el ejercicio del poder penal estatal ${ }^{4}$.

Por otra parte, aun cuando no está expresamente reconocido en nuestra carta fundamental, nadie discute su vigencia en el sistema jurídico chileno ${ }^{5}$, al punto que nuestro Tribunal Constitucional ha debido pronunciarse sobre la eventual inconstitucionalidad de diversas disposiciones en relación con una posible infracción de este principio y ha llegado a aceptar los requerimientos de inaplicabilidad en varias ocasiones ${ }^{6}$.

\footnotetext{
${ }^{1}$ PASTOR, Daniel Roberto, Tendencias hacia una aplicación más imparcial del Derecho penal, Buenos Aires: Hammurabi, 2012, p. 139.

${ }^{2}$ MAÑALICH, Juan Pablo, "El principio ne bis in idem en el Derecho penal chileno", Revista de Estudios de la Justicia, $\mathrm{N}^{\circ} 15$ (2011), p. 140, las caracteriza como un estándar sustantivo de aplicación jurisdiccional de normas de sanción penal y un estándar de clausura procesal, respectivamente.

${ }^{3}$ Por todos PÉREZ MANZANO, Mercedes, La prohibición constitucional de incurrir en bis in idem, Valencia: Tirant lo Blanch, 2002, p. 71 con ulteriores referencias.

${ }^{4}$ Cfr. OTTAVIANO, Santiago, La garantía del ne bis in idem. La prohibición de doble sanción y de doble enjuiciamiento penal y su tutela en los tratados internacionales de Derechos Humanos, México: Porrúa, 2013, p. XXXIII.

${ }^{5}$ Lo que se cuestiona, más bien, es que no se haya incluido expresamente en la Constitución política, así ETCHEBERRY, Alfredo, Derecho penal. Parte general, Tomo II, $3^{a}$ ed., Santiago: Ed. Jurídica de Chile, 1998, p. 71, quien lo considera ínsito en un sistema liberal (p. 108) y GARRIDO MONTT, Mario, Derecho penal. Parte general, Tomo I, $2^{\mathrm{a}}$ ed., reimpresión, Santiago: Ed. Jurídica de Chile, 2009, p. 158. Vid. también COUSIÑO MACIVER, Luis, Derecho penal chileno. Parte general, Tomo I, Santiago: Ed. Jurídica de Chile, 1975, pp. 166 y 199; POLITOFF, Sergio; MATUS, Jean Pierre; RAMÍREZ, María Cecilia, Lecciones de Derecho Penal chileno. Parte General, $2^{\mathrm{a}}$ ed., Santiago: Ed. Jurídica de Chile, 2004, p. 522, n. 99.

${ }^{6}$ Los requerimientos se han presentado en relación con diversas disposiciones:
} 
Polit. crim. Vol. 13, No 26 (Diciembre 2018) Art. 8, pp. 952-1002.

[http://www.politicacriminal.cl/Vol_13/n_26/Vol13N26A8.pdf]

Pero fuera de estos aspectos elementales todo parece ser objeto de controversia o de diversidad de opiniones en torno al ne bis in idem; desde su propia denominación (si es non o $n e^{7}$ ), su naturaleza jurídica (si es una regla o un principio ${ }^{8}$, un derecho o una garantía), si es un único principio o dos prohibiciones diferentes ${ }^{9}$, el fundamento de cada una de sus vertientes, sus destinatarios (si obliga solo a los jueces o también al legislador), el alcance mismo de la prohibición, etc.

a) Artículo 207 letra b) de la Ley $N^{\circ}$ 18.290: ha sido declarado inaplicable en las SSTC Rol No 2045, 7 de junio de 2012; Rol No 2254, 18 de diciembre de 2012; Rol No 2896, 25 de agosto de 2016 y Rol No 3000, 10 de enero de 2017. Dicha disposición establece que "al responsable de dos infracciones o contravenciones gravísimas cometidas dentro de los últimos doce meses, la licencia se suspenderá de 45 a 90 días y al responsable de dos infracciones o contravenciones graves cometidas dentro de los últimos doce meses, de 5 a 30 días". En sus últimas resoluciones, luego de algunos cambios en su conformación, se advierte una consolidación de esta posición al interior del Tribunal Constitucional. Con anterioridad, en algunas ocasiones el voto mayoritario había sido por rechazar el recurso (SSTC Rol No 2402 y 2403, 8 de noviembre de 2013) o había existido un empate de votos lo que, atendido el quórum calificado exigido para acoger esta clase de requerimientos, había llevado a tenerlos por desechados (SSTC Rol No 1960 y 1961, 10 de julio de 2012; Rol $\mathrm{N}^{\mathrm{o}} 2018$ y 2108, 7 de agosto de 2012; y Rol No 2236, 30 de abril de 2013).

b) Artículo 433 del Código de Justicia Militar: la vulneración del principio ne bis in idem sirvió, entre otros motivos, para declarar su inaplicabilidad, en la STC Rol No 2773, 28 de enero de 2016.

c) Artículo $4^{o}$ de la Ley $N^{\circ}$ 19.886: permite que, habiendo sido condenado por infringir los derechos fundamentales del trabajador, al empleador se le sancione además con la prohibición de contratar con la Administración. En tres oportunidades el Tribunal Constitucional ha rechazado los respectivos requerimientos de inconstitucionalidad, pero en todos ellos con voto disidente de tres ministros (SSTC Rol No 1968,15 de mayo de 2012; Rol No 2133, 4 de julio de 2013 y Rol No 2722, 15 de octubre de 2015).

d) Artículos 34 y 35 del DFL N 2 del Ministerio del Trabajo y Previsión Social: permiten a los Inspectores del Trabajo clausurar un establecimiento o faena hasta por 10 días, en caso de que exista una nueva infracción que se cometa dentro de los dos años siguientes a la fecha de la última multa o clausura, sanción que se puede imponer sin perjuicio de la procedencia de la multa administrativa que corresponda por la infracción individualmente considerada. El requerimiento presentado contra esta disposición fue tenido por rechazado, por resultar igualdad de votos por acoger y rechazar (STC Rol No 2346, 16 de enero de 2014).

${ }^{7}$ Vid. los argumentos de esta discusión en DE LEÓN VILLALBA, Francisco Javier, Acumulación de sanciones penales y administrativas: sentido y alcance del principio "ne bis in idem", Barcelona: Bosch, 1998, p. 35 y 36; LÓPEZ BARJA DE QUIROGA, Jacobo, El principio: non bis in idem, Madrid: Dykinson, 2004, p. 17; MUÑOZ CLARES, José, Ne bis in idem y derecho penal. Definición, patología y contrarios, Murcia, Ed. Diego Marín, 2006, pp. 25-28 y OTTAVIANO, La garantía, cit. nota ${ }^{\circ}$ 4, p. 1-4, quien advierte que no es más que un problema de matices, pues ambas expresiones -non o ne- evidencian la negación de lo que es el núcleo problemático de la frase: el bis in idem.

${ }^{8}$ Disquisiciones cuya relevancia ha sido desestimada, en tanto lo decisivo "es simplemente el alcance de la prohibición que siempre es el mismo se la trate de regla o principio" PASTOR, Tendencias, cit. nota $\mathrm{n}^{\mathrm{o}} 1$, $\mathrm{p}$. 141, y lo mismo ocurre en relación con su reconocimiento como derecho o garantía. Vid. también FALLET LA ROCCA, Lucas, ¿Es posible pensar el non bis in idem como una garantía unitaria? Estudio de los sistemas español y argentino, con referencia a la jurisprudencia de tribunales internacionales, Buenos Aires: Fabián J. Di Plácido Editor, 2015, p. 36.

${ }^{9}$ Subrayan la necesidad de diferenciar las dos facetas de la prohibición, especialmente en lo que dice relación con el fundamento de cada una de ellas, OTTAVIANO, La garantía, cit. nota ${ }^{\circ}$ 4, pp. 121-122 y PÉREZ MANZANO, La prohibición, cit. nota n 3, pp. 67 y ss. Entre nosotros MAÑALICH, Juan Pablo, "El principio ne bis in idem frente a la superposición del derecho penal y el derecho administrativo sancionatorio", Polít. Crim., vol. 9, N 18 (2014), A8, pp. 547-548. 
En buena medida, ello se debe a que muchas de estas cuestiones se resuelven en función del contexto político que existe en cada momento, pues "el aforismo ne bis in idem, que nace como una regla de lógica discursiva, se traslada al ámbito jurídico como instrumento de solución a la constante tensión entre la seguridad formal y la justicia material. De ahí, que en cada momento histórico se acepte o se niegue la aplicación de la prohibición de no valoración de dos veces lo mismo, en función de la propia configuración del sistema jurídico e indirectamente del orden político"10.

\section{Reconocimiento constitucional}

Como ya hemos indicado, el ne bis in idem goza de un reconocimiento generalizado como un principio limitador del ius puniendi estatal, en orden a garantizar las libertades y derechos básicos de las personas ${ }^{11}$; un límite a la potestad penal basado en la protección de la dignidad de la persona en un Estado de Derecho ${ }^{12}$.

Nuestra Corte Suprema lo ha considerado una garantía individual innominada, originaria del Derecho Natural $^{13}$, lo que bien puede relacionarse con el hecho de que es un principio que está conectado con exigencias de justicia, válidas para cualquier rama del Derecho. "Ya los romanos decían: Bona fides non patitur ut bis idem exigatur, y ello es así tanto para imponer una pena como para cobrar una deuda"14.

${ }^{10}$ DE LEÓN VILLALBA, Francisco Javier, "Sobre el sentido del axioma ne bis in idem", en: ARROYO ZAPATERO, Luis y NIETO MARTÍN, Adán (coords.), 2007): El principio de ne bis in idem en el derecho penal europeo e internacional, Cuenca, Ediciones de la Universidad Castilla-La Mancha, 2007, p. 26. Para NIETO GARCÍA, Alejandro, Derecho Administrativo Sancionador, $4^{\mathrm{a}}$ ed., reimpresión, Madrid: Tecnos, 2006, p. 470, la regla surgió "como creación doctrinal, dominada por inequívocas inspiraciones ideológicas". En el sistema jurídico español ello es bien evidente, pues con anterioridad a la entrada en vigor de la Constitución regía el llamado principio de independencia de la potestad administrativa que permitía la plena compatibilidad entre pena y sanción administrativa; luego, aunque el principio no fue expresamente recogido en el texto de la carta fundamental, el Tribunal Constitucional se encargó de reconocerlo y extender su aplicación a todo el ámbito sancionador, haciéndose eco de lo que ya demandaba tiempo atrás la doctrina. Cfr. GÓRRIZ ROYO, Elena, "Sentido y alcance del ne bis in idem respecto a la preferencia de la jurisdicción penal, en la jurisprudencia constitucional (En especial la STC 2/2003, 16 de enero)", Estudios penales y criminológicos, $\mathrm{N}^{\circ}$ 24 (2003), pp. 196-198.

11 "Estamos frente a un cerco protector constituido a favor del individuo y que las fuerzas estatales no deben traspasar", FALLET, ¿Es posible ..., cit. nota n ${ }^{\circ}$, p. 36

${ }^{12}$ Cfr. OTTAVIANO, La garantía, cit. nota $\mathrm{n}^{\mathrm{o}}$ 4, pp. 102-111. En nuestro Tribunal Constitucional, por todas, STC Rol No 3000, 10 de enero de 2017, considerando $7^{\circ}$.

${ }^{13}$ SCS Rol No 5889-2004, de 11 de julio de 2006, cuarta sala, citando a Juan Carlos Cassagne, La Intervención Administrativa, Abeledo Perrot, Buenos Aires, 2004, p. 231; cita que reitera en numerosas sentencias posteriores, vgr. SSTS Rol No 196-2009, Rol No 148-2010, Rol No 1071-2012 y Rol No 1333-2013.

${ }^{14}$ OTTAVIANO, La garantía, cit. nota $\mathrm{n}^{\circ}$ 4, p. 51, citando un párrafo del Digesto atribuido a Gayo: D.50, 17, fragmento 57. 
Polit. crim. Vol. 13, № 26 (Diciembre 2018) Art. 8, pp. 952-1002.

[http://www.politicacriminal.cl/Vol_13/n_26/Vol13N26A8.pdf]

Aunque carece de consagración expresa en la Constitución Política -como ocurre también en muchos otros ordenamientos jurídicos ${ }^{15}$ - nuestra jurisprudencia constitucional le confiere rango constitucional por vía indirecta ${ }^{16}$, pues estima que esta prohibición

"ha de entenderse que forma parte del conjunto de derechos que los órganos del Estado deben respetar y promover en virtud del mandato contenido en el inciso segundo del artículo $5^{\circ}$ de la Constitución, el que reconoce como fuente de esos derechos tanto a la propia Carta Fundamental como a los tratados internacionales ratificados por Chile y que se encuentran vigentes" 17 .

En este caso, la alusión corresponde al Pacto Internacional de Derechos Civiles y Políticos de 1966, cuyo artículo $14 \mathrm{~N}^{\circ} 7$ establece que " [n] adie podrá ser juzgado ni sancionado por un delito por el cual ya haya sido condenado o absuelto por una sentencia firme de acuerdo con la ley y el procedimiento penal de cada país"; y a la Convención Americana de Derechos Humanos de 1969, que en su artículo 8 N 4 indica que "[e]l inculpado absuelto por una sentencia firme no podrá ser sometido a nuevo juicio por los mismos hechos".

Además de lo anterior, el Tribunal Constitucional -en una posición que en la actualidad es claramente mayoritaria- añade una serie de argumentos diversos para fundamentar la vigencia del principio en nuestro orden jurídico:

“...es una base esencial de todo ordenamiento penal democrático el principio de que por un mismo hecho delictivo el responsable no puede sufrir más de una pena o ser objeto de más de una persecución criminal, conocido como el non bis in idem. Esta interdicción del juzgamiento y la sanción múltiples se sustenta, respectivamente, en la aplicación de principios relativos al debido proceso y la proporcionalidad.

Su fundamento constitucional deriva de la dignidad personal y del respeto a los derechos esenciales que emanan de la naturaleza humana, cualidad que le es reconocida universalmente. Su transgresión constituye, pues, un atropello de las bases de la institucionalidad, así como de las garantías de un procedimiento e investigación racionales y justos, consagradas en el capítulo sobre igual protección de la ley en el ejercicio de los derechos" ${ }^{18}$.

En términos muy similares, la Corte Suprema afirma que el sustento de la garantía

\footnotetext{
${ }^{15}$ Más bien lo excepcional es que sea consagrado en forma explícita, algo que se da en las Constituciones de Alemania, Colombia, Costa Rica, Estados Unidos y México.

16 Situación equivalente a la de otros países. Así, por ejemplo, en Argentina se consideraba un derecho constitucional no numerado hasta 1994, año en que la garantía se considera incorporada por intermedio del art. 75 inc. 22 de la Constitución, que jerarquiza diversos instrumentos internacionales de derechos humanos que sí la consideran expresamente. En este sentido FALLET, ¿Es posible ..., cit. nota no 8, p. 104.

${ }^{17}$ STC Rol No 1968,15 de mayo de 2012, considerando $41^{\circ}$ (por todas).

${ }^{18}$ STC Rol N ${ }^{\mathrm{o}} 2045,7$ de junio de 2012, considerando $4^{\text {o }}$; reiterado en los mismos términos en las SSTC Rol $\mathrm{N}^{\mathrm{o}}$ 2254, 18 de diciembre de 2012; Rol No 2773, 28 de enero de 2016; Rol No 2896, 25 de agosto de 2016 y Rol $\mathrm{N}^{\mathrm{o}}$ 3000, 10 de enero de 2017. También en los votos por acoger el requerimiento de las SSTC Rol No 1960 y 1961, 10 de julio de 2013 y Rol No 2018 y 2108, 7 de agosto de 2012.
} 
"se halla en el debido proceso legal exigido por el $\mathrm{N}^{\mathrm{o}} 3$ del artículo 19 y en la idea de que al admitirse una segunda condena por la misma infracción se produce una manifiesta desproporción entre la falta y su castigo" 19 .

Como se advierte en los textos transcritos, a pesar de que originalmente el ne bis in idem no se consideraba comprendido entre las garantías que implica el debido proceso $^{20}$, se ha consolidado ahora la idea de que sí es parte del mismo, y de este modo ha sido posible asignarle un lugar concreto en el texto de nuestra Constitución, en su artículo $19 \mathrm{~N}^{\mathrm{o}} 3$ párrafo sexto.

Ahora bien, este carácter supralegal de la garantía resulta predicable en forma indubitada únicamente respecto de su faz procesal, pues en principio parece que solo ella queda comprendida en el derecho al debido proceso y porque en los tratados internacionales que sirven de fuente para su reconocimiento constitucional, el aspecto procesal sería el único que quedaría plenamente consagrado como garantía. En efecto, el artículo $8^{\circ} \mathrm{N}^{\circ} 4$ de la Convención Americana de Derechos Humanos contiene una fórmula muy restringida que solo prohíbe un nuevo juicio por los mismos hechos ${ }^{21}$. La norma del Pacto Internacional de Derechos Civiles y Políticos, en tanto, es bastante más amplia y alude a la imposibilidad de ser juzgado "o sancionado", con lo que parece abarcar tanto la dimensión procesal como la sustantiva del principio; sin embargo, restringe la garantía únicamente a los casos en que existe una sentencia condenatoria o absolutoria firme, de modo tal que no proscribe la doble sanción o la doble valoración de un mismo hecho para fundamentar o agravar la pena siempre que eso ocurra dentro de un mismo procedimiento ${ }^{22}$.

Con todo, para evitar que el sentido sustantivo del ne bis in idem quede despojado de reconocimiento en nuestra Carta Fundamental, el mismo Tribunal Constitucional ha

\footnotetext{
${ }^{19}$ SCS Rol N ${ }^{\text {o }}$ 5889-2004, 11 de julio de 2006, cuarta sala; también en sentencias posteriores, siempre de la misma sala y en temas laborales, vgr. SSTS Rol No 196-09, Rol No 148-2010, Rol No 10771-2012 y Rol No 1333-2013.

${ }^{20} \mathrm{Al}$ enunciar los presupuestos mínimos del debido proceso, el Tribunal Constitucional no incluía la regla del ne bis in idem (vid. SSTC Rol No 1518, 21 de octubre de 2010, considerando 23, y Rol No 1448,7 de noviembre de 2010, considerando $40^{\circ}$ ); incluso había calificado esa posibilidad como "compleja" (STC Rol N 1441,4 de noviembre de 2009, considerando decimoprimero) buscando alternativas para fundamentarla (STC Rol N ${ }^{\circ}$ 1968, 15 de mayo de 2012, considerando 41). La doctrina tampoco incluye la prohibición de bis in idem en la garantía del debido proceso, vid. por todos, FERNÁNDEZ CRUZ, José Ángel, "Tribunal constitucional y derecho penal: un estudio crítico", Estudios Constitucionales, Año 12, Nº 2 (2014), p. 228 y GARCÍA PINO, Gonzalo - CONTRERAS VÁSQUEZ, Gonzalo, "El derecho a la tutela judicial y al debido proceso en la jurisprudencia del Tribunal Constitucional chileno", Estudios Constitucionales, Año 11, No 2 (2013), pp. 238239.

${ }^{21}$ Más todavía, alude únicamente al inculpado absuelto como destinatario de la garantía, lo que permitiría sostener que el inculpado previamente condenado podría ser sometido a un nuevo juicio. Sin embargo, una interpretación mínimamente razonable de la norma permite abarcar ambos supuestos, según ha entendido la propia Corte Interamericana. Vid. OTTAVIANO, La garantía, cit. nota n 4, pp. 159-160.

${ }^{22}$ En este sentido MAÑALICH, "El principio", cit. nota ${ }^{\circ} 2$, pp. 141-142.
} 
Polít. crim. Vol. 13, No 26 (Diciembre 2018) Art. 8, pp. 952-1002.

[http://www.politicacriminal.cl/Vol_13/n_26/Vol13N26A8.pdf]

establecido una vinculación de las garantías procesales con cuestiones de fondo, en relación con la posibilidad de doble sanción. Ha declarado que:

"tales garantías no se restringen a la observancia de la ritualidad formal de un proceso, sino que alcanzan a los elementos materiales o sustanciales del trato que surge de la aplicación de la norma procesal, en orden a asegurar la justicia de la decisión jurisdiccional. En ese sentido, el procedimiento que permite juzgar y sancionar más de una vez por el mismo hecho desafía toda noción de justicia"²3.

Por otra parte, si consideramos la importancia de la consagración expresa del ne bis in idem en los instrumentos internacionales ${ }^{24}$ y la posibilidad de recurrir a un criterio de interpretación pro homine en el ámbito de los derechos humanos, que lleva a adoptar la interpretación extensiva de las normas si resulta más favorable a la persona humana ${ }^{25}$, es posible concluir que "la idea general de proceso con las debidas garantías o proceso equitativo incluye, en el contexto del Derecho Internacional de los Derechos Humanos tanto garantías procesales como garantías sustanciales y (...) es entendido por los órganos internacionales como el contexto normativo natural de ambas vertientes del ne bis in idem" 26 .

Por último, debemos señalar que el Tribunal Constitucional también ha invocado el párrafo noveno del $\mathrm{N}^{\mathrm{o}} 3$ del artículo 19 de la Carta Fundamental para dar cobertura al principio ne bis in idem. En él se dispone que "ninguna ley podrá establecer penas sin que la conducta que se sanciona esté expresamente descrita en ella", lo que impediría una segunda condena por un mismo hecho si no existe la descripción de una nueva conducta que dé pie a una nueva

${ }^{23}$ STC Rol No 2045, 7 de junio de 2012, considerando $4^{\circ}$. También en el voto por acoger, STC Rol № 2346 , 16 de enero de 2014, se afirma que "el derecho a un procedimiento justo y racional no sólo se refiere aspectos adjetivos oformales, de gran trascendencia como el acceso a la justicia de manera efectiva y eficaz, sino que también comprende elementos sustantivos de significativa connotación material $\left(\right.$ Rol $N^{\circ} 437$, considerando 14), como es -entre otras dimensiones-garantizar la proporcionalidad de las medidas adoptadas en su virtud. Esto es, en los procesos punitivos, que exista una relación de equilibrio entre la sanción impuesta y la conducta imputada".

${ }^{24}$ En este sentido FALLET, ¿Es posible ..., cit. nota $\mathrm{n}^{\mathrm{o}}$ 8, p. 45.

${ }^{25}$ Cfr., en general, HENDERSON, Humberto, "Los tratados internacionales de derechos humanos en el orden interno: la importancia del principio pro homine", Revista del Instituto Interamericano de Derechos Humanos, vol. 39 (2004), pp. 71-99, pp. 88-89. En el contexto de la interpretación de algunos aspectos concretos relativos al ne bis in idem (como qué se entiende por infracción o por sentencia firme), vid. FALLET, ¿Es posible ..., cit. nota $\mathrm{n}^{\circ} 8$, p. 45.

${ }^{26}$ OTTAVIANO, La garantía, cit. nota $\mathrm{n}^{\circ}$ 4, pp. 100-101. En Estados Unidos la alusión al due process es entendida de una forma cercana a lo que, entre nosotros, constituye una concepción material del Estado de Derecho, en el sentido de que no exige únicamente una adecuación estricta de los órganos estatales a los procedimientos establecidos en la ley, sino que también garantiza la posibilidad de acudir a la magistratura federal para la protección de los derechos constitucionales. Pero sin llegar tan lejos, se puede igualmente vincular las dos vertientes del principio con la idea de debido proceso, proceso equitativo o proceso con todas las garantías, si se considera que la prohibición de bis in idem se orienta a evitar la repetición formalizada de sanciones o persecuciones penales; es decir, que tiene sentido como prohibición de una multiplicidad de sanciones o persecuciones mediante los mecanismos de persecución o aplicación de sanciones previstos en el sistema jurídico, obrando en el marco de un procedimiento jurisdiccional. Cfr. OTTAVIANO, La garantía, cit. nota $n^{\circ} 4$, p. $112-116$ 
OSSANDÓN, Magdalena. "El legislador y el principio ne bis in idem".

consecuencia punitiva ${ }^{27}$. Ahora bien, esta explicación tiene sentido en relación con aquellas disposiciones -como, por ejemplo, el art. 207 letra b) de la Ley $\mathrm{N}^{\mathrm{o}} 18.290^{28}$ - en que no existe una nueva descripción de la conducta a la que se asocia la sanción adicional, pero no es aplicable para impugnar los supuestos en que concurran diversas disposiciones para sancionar una misma conducta que esté perfectamente descrita en cada una de ellas.

Las consideraciones anteriores permiten concluir que, aunque no esté explícitamente consagrado en la Constitución, el principio ne bis in idem es parte del sistema jurídico y goza de reconocimiento, al menos indirecto, en nuestro régimen constitucional. Por lo tanto, tiene valor supralegal.

Ahora bien, considerando lo que ha sido la experiencia comparada y nacional, cabe advertir que ni su reconocimiento explícito ni su inferencia a partir de otros textos han supuesto que se adopten soluciones coherentes y sistemáticas para asegurar que el principio sea efectiva y plenamente acatado ${ }^{29}$. Entre las tantas cuestiones discutidas sobre su alcance está, precisamente, la del destinatario de la prohibición. Así, aunque es incuestionable que el juez debe respetarla, no resulta tan claro si el legislador queda obligado en alguna medida -y en qué medida-por el ne bis in idem.

\section{Destinatario de la prohibición y control constitucional}

La prohibición de sancionar dos veces por lo mismo alcanza indiscutiblemente a quien decide, en concreto, sobre la imposición de las sanciones. Es evidente que al juez le está vedado valorar de manera duplicada un mismo hecho o circunstancia para imputar responsabilidad e imponer sanciones.

En cambio, existen opiniones encontradas al discernir si el ne bis in idem obliga también al legislador a la hora de forjar las normas que integran el ordenamiento jurídico, tanto al interior del sistema penal y del sistema administrativo, respectivamente, como, sobre todo, en la coordinación entre ambos.

\footnotetext{
${ }^{27}$ Argumento contenido en el voto por acoger el requerimiento, de minoría, en las SSTC Rol No 2402 y 2403 , 8 de noviembre de 2013; en el voto por acoger, empatado con el de rechazar, en la STC 2236, 30 de abril de 2013, y en el voto mayoritario por acoger la inaplicabilidad de las SSTC Rol No 2896, 25 de agosto de 2016 y Rol No 3000, 10 de enero de 2017.

${ }^{28}$ Artículo 207. Sin perjuicio de las multas que sean procedentes, el Juez decretará la suspensión de la licencia de conducir del infractor, en los casos y por los plazos que se indican a continuación: (...) b) Tratándose de procesos por acumulación de infracciones, al responsable de dos infracciones o contravenciones gravísimas cometidas dentro de los últimos doce meses, la licencia se suspenderá de 45 a 90 días y al responsable de dos infracciones o contravenciones graves cometidas dentro de los últimos doce meses, de 5 a 30 días.

${ }^{29}$ En este sentido FALLET, ¿Es posible..., cit. nota ${ }^{\circ} 8$, p. 41.
} 
Polít. crim. Vol. 13, No 26 (Diciembre 2018) Art. 8, pp. 952-1002.

[http://www.politicacriminal.cl/Vol_13/n_26/Vol13N26A8.pdf]

Así, aunque una buena parte de la doctrina considera que el legislador es el principal destinatario de este mandato ${ }^{30}$, parece ser mayoritaria la opinión de que no le es vinculante ${ }^{31}$, al menos no directamente ${ }^{32}$, pues lo que el principio ne bis in idem prohíbe es que un mismo hecho sea doblemente sancionado, no que sea doblemente tipificado. Por ejemplo, el Tribunal Supremo español es bien enfático: "su cumplimiento, insistimos, corresponde, no al que elabora y aprueba la norma, sino al que la aplica en aquellos supuestos en que un mismo acto o hecho pueda estar tipificado y sancionado en más de un precepto punitivo" 33 .

Desde esta posición se llega a afirmar, incluso, que existiendo una doble tipificación de una misma conducta "si hay base suficiente para atribuir al legislador la sobrevaloración de una misma propiedad de determinado hecho, entonces esa sobrevaloración no es prima facie interpretable como redundancia, sino como énfasis en su valoración negativa" ${ }^{34}$. En

30 En Chile CORDERO QUINZACARA, Eduardo, Derecho administrativo sancionador, Santiago: Legal Publishing-Thomson Reuters, 2014, p. 265. En España, paradigmático, GARCÍA DE ENTERRÍA, Eduardo, La Constitución como norma y el Tribunal Constitucional, Madrid: Civitas, 1985, pp. 246-247, entiende, sobre la base de la consagración constitucional del principio de legalidad, que "una determinada acción u omisión estará incluida en un tipo penal o en un tipo de infracción administrativa, nunca simultáneamente en ambos, y esa inclusión, en todo caso, tendrá que ser obra de la Ley". Similar CANO MATA, Antonio, "Potestad normativa sancionadora de las Comunidades Autónomas", Revista de Administración Pública, № 119 (1989), p. 215. Desde otro punto de vista, CUERDA RIEZU, Antonio, "El concurso de delitos en el Borrador de anteproyecto de Código Penal de 1990", Anuario de Derecho Penal y Ciencias Penales, Tomo 44, N 3 (1991), p. 848 , considera que la doctrina del Tribunal Constitucional español que confiere carácter de derecho fundamental al ne bis in idem tiene implicancias para el legislador, porque "cualquier norma que atente contra la doctrina sentada en la resolución transcrita será claramente inconstitucional". DE LEÓN VILLALBA, Acumulación, cit. nota $\mathrm{n}^{\mathrm{o}}$ 7, p. 175 sostiene que el ne bis in idem se basa en la seguridad jurídica -necesariamente vinculada al principio de legalidad - y que "debe proyectarse al momento mismo de toma de decisión por parte del legislador de la creación de las normas sancionadoras y al proceso de construcción de los propios ilícitos". Menos evidente, pero en la misma línea, ARROYO ZAPATERO, Luis, "Principio de legalidad y reserva de ley en materia penal", Revista Española de Derecho Constitucional, N ${ }^{\circ} 8$ (1983), pp. 19 y 20. También HORMAZÁBAL MALARÉE, Hernán; BUSTOS RAMÍREZ, Juan José "Principio de legalidad y ne bis in idem", en: CARBONELL MATEU, Juan Carlos (coord.), Estudios penales en Homenaje al Profesor Cobo del Rosal, Madrid: Dykinson, 2005, p. 165, distinguen dos niveles de operatividad del ne bis in idem: el de creación de la norma y el de su aplicación.

${ }^{31}$ Por todos, GARCÍA ALBERO, Ramón, Non bis in idem material y concurso de leyes penales, Barcelona: Cedecs, 1995, p. 79; MAÑALICH, "El principio ne bis in idem frente a la superposición", cit. nota n 9, p. 549; NIETO GARCÍA, Derecho Administrativo Sancionador, cit. nota no 10, pp. 476-477 y 486 y RAMÍREZ GÓMEZ, Salvador, El principio ne bis in idem en el ámbito tributario (Aspectos sustantivos y procedimentales), Madrid-Barcelona: Marcial Pons, 2001, p. 49.

${ }^{32}$ MAÑALICH, "El principio", cit. nota no 2, p. 143.

${ }^{33}$ STS español 1594/1985 de 15 de marzo, FJ 4; también la STS 3817/2000, de 24 de abril, FJ 5, señala: “el non bis in ídem no se vulnera por una doble tipificación del mismo hecho, es decir, porque exista un concurso de normas punitivas, sino sólo cuando se apliquen las dos normas"; (Hay que distinguir) "entre la doble sanción por unos mismos hechos y la previsión de la misma infracción en distintas normas, pues cuando menos, en principio, ello no afecta al principio non bis in ídem, que lo que prohíbe no es una distinta regulación y sí una doble sanción por unos mismos hechos". En similares términos se pronuncia el Tribunal Constitucional de España, vgr. SSTC 159/1985, de 27 de noviembre; 2/2003, de 16 de enero y 334/2005, de 20 de diciembre.

${ }^{34}$ MAÑALCH, "El principio", cit. nota $n^{\circ}$ 2, p. 143, MAÑALICH, "El principio ne bis in idem frente a la superposición", cit. nota n ${ }^{\circ}$, p. 549, agrega que incluso si se aceptara la "razonabilidad de un modelo regulativo 
consecuencia, el legislador podría recurrir a la duplicidad de sanciones respecto de una misma conducta, teniendo como límite únicamente las exigencias del principio de proporcionalidad ${ }^{35}$, un estándar supralegal que "jamás podrá ser identificado con el principio ne bis in idem" 36 .

La solución de esta controversia es de particular relevancia para la labor del Tribunal Constitucional a la hora de enjuiciar un determinado precepto y sus posibilidades de aplicación. Si se estima que el legislador resulta obligado por la prohibición, existiría la posibilidad de calificar como inconstitucional, eventualmente también en abstracto, una disposición que realice una doble valoración de un mismo hecho o circunstancia para aplicar un segundo castigo. De lo contrario, el control debería limitarse únicamente $-\mathrm{y}$ en la medida en que sea posible- al juicio de proporcionalidad, sin que pudiera objetarse el hecho de que se estipulen varias sanciones para un mismo hecho ${ }^{37}$.

Precisamente, al analizar la posible vulneración del ne bis in idem, al interior de nuestro Tribunal Constitucional se han definido dos posiciones que están, en principio, condicionadas por posiciones antagónicas en torno a la cuestión que nos ocupa. Aunque las argumentaciones de cada una sobre el destinatario de la prohibición son algo confusas, se pueden rescatar ciertas pautas que tienen especial relevancia en la decisión.

\subsection{Posición a favor de declarar la inaplicabilidad por inconstitucionalidad de ciertas normas por vulneración del principio ne bis in idem}

En los votos por acoger los recursos y declarar la inaplicabilidad de los preceptos impugnados destaca el hecho de que se haga un análisis separado del ne bis in idem, por una parte, y de

que pudiera condicionar la aplicación de normas de sanción administrativa a la falta de aplicación de normas de sanción penal en relación con un mismo hecho [...] el legislador no se encuentra obligado a adoptar semejante modelo regulativo, precisamente porque, por definición, el legislador no resulta alcanzado por la prohibición de punición múltiple".

35 "Si la doble sanción no resulta arbitraria y desproporcionada tampoco afectaría al principio" dice ARROYO, "Principio de legalidad", cit. nota $\mathrm{n}^{\circ}$ 30, p. 19. En el mismo sentido MAÑAICH, "El principio ne bis in idem frente a la superposición", cit. nota ${ }^{\circ} 9$, pp. 558-559.

${ }^{36}$ MAÑLICH, "El principio ne bis in idem frente a la superposición”, cit. nota nº 9, p. 549.

${ }^{37}$ La controversia es más amplia, como queda de manifiesto en la STC Rol No 2995-16, 17 de marzo de 2017. El voto disidente, en su considerando $8^{\circ}$, delimita las fronteras constitucionales de la política criminal sobre la base de que el legislador tiene primacía en la creación de ésta. Solo estaría sujeto a algunos límites expresamente estipulados en la Constitución los que, salvo la referencia a la dignidad humana, son muy restrictivos y puntuales. No se incluye entre ellos ningún principio limitador del ius puniendi en cuanto tal, sino en la medida en que alguna de sus manifestaciones concretas haya sido recogida en el texto constitucional (como ocurre con algunos aspectos de los principios de legalidad y culpabilidad). Por el contrario, el considerando $17^{\circ}$ de la sentencia defiende la existencia de límites formales y sustantivos para el legislador, "encarnados en exigencias y prohibiciones de alcance global y que nuestra Constitución reconoce en forma expresa o implícita. Principios tales como los de legalidad (y tipicidad), prohibición de doble valoración (ne bis in idem), prohibición de presumir de derecho la responsabilidad penal, prohibición de la autoincriminación, aplicación de la ley penal más favorable o [...] el de prohibición de desproporción excesiva". 
Polit. crim. Vol. 13, № 26 (Diciembre 2018) Art. 8, pp. 952-1002.

[http://www.politicacriminal.cl/Vol_13/n_26/Vol13N26A8.pdf]

la proporcionalidad, por otra ${ }^{38}$. Se les considera criterios independientes y de raigambre constitucional, por lo que ambos obligarían al legislador.

Bajo estas premisas, resulta posible estimar infringida la prohibición de ne bis in idem cuando la ley estipula o permite la imposición de dos sanciones para una misma conducta, con independencia de que la aplicación conjunta de estas sanciones resulte o no resulte desproporcionada. Por eso se ha llegado a afirmar que:

"del propio tenor de la norma cuestionada se infiere que ella vulnera el principio ne bis in idem, en la medida que sanciona toda falta contra los deberes militares o la disciplina de conformidad a las normas reglamentarias pertinentes, pero además agrega que podrá ser ejercida a su respecto una acción penal cuando las circunstancias conexas lleven a la configuración de un delito" 39 .

Es decir, el propio legislador se vería limitado por las exigencias formales del principio ne bis in idem al adoptar su decisión, más allá de las restricciones materiales que impone el principio de proporcionalidad -como aclara el ministro Romero en un voto de prevenciónpues,

"no se discute la procedencia del amplio margen de apreciación o flexibilidad que goza el legislador al momento de configurar un sistema sancionatorio, pero esto no lo inmuniza frente a un control de constitucionalidad de la ley (...) un ajuste en la reacción punitiva del Estado no puede, desde el punto de vista constitucional, diseñarse de cualquier forma" ${ }^{40}$.

\subsection{Posición contraria a la declaración de inaplicabilidad por inconstitucionalidad por vulneración del principio ne bis in idem}

\footnotetext{
${ }^{38}$ Vgr. en la STC Rol No 2045, 7 de junio de 2012, la infracción al ne bis in idem se declara en el considerando $5^{\circ}$, y la de proporcionalidad en el $8^{\circ}$. Esta última, no se hace radicar en la duplicidad de sanciones, sino en que "a las dos penas de multa impuestas por dos infracciones graves, cualesquiera que éstas sean, se adiciona la de suspender la licencia de conducir sin tener en cuenta si las conductas en que incurrió anteriormente el infractor o los antecedentes del mismo, revelan una especial peligrosidad que amerite la aplicación de la suspensión de la licencia de conducir" (el destacado es nuestro). En la STC Rol № 3000, 10 de enero de 2017, por su parte, el análisis relativo a la infracción del ne bis in idem y de la proporcionalidad se realiza bajo distintos epígrafes. ${ }^{39}$ STC Rol No 2773, 28 de enero de 2016, considerando 33 (considerando aprobado por seis ministros; mientras que dos ministros previnieron que concurrían a la sentencia sin compartir lo allí señalado y existió un voto en contra). El precepto analizado era el art. 433 del Código de Justicia Militar.

${ }^{40}$ STC 2896, 25 de agosto de 2016, voto de prevención, considerando $6^{\circ}$. Previamente, en el considerando $4^{\circ}$, luego de constatar que concurre la triple identidad afirmaba claramente que "es posible sostener que el diseño legislativo impugnado viola el principio non bis in ídem y, por ende, la Constitución”.

En el mismo sentido, el voto por acoger, disidente, en la STC Rol № 2897, 5 de julio de 2017, reconoce que el legislador tiene el legítimo derecho a ponderar de diversas maneras las circunstancias que respaldan su decisión, "el problema constitucional respecto del tema específico analizado en este apartado radica, no obstante, en la forma jurídica en que se ha concretado legislativamente. El diseño legal, para casos como el de autos, tiene un efecto punitivo redundante" (considerando $19^{\circ}$ ).
} 
OSSANDÓN, Magdalena. "El legislador y el principio ne bis in idem".

Los ministros que se han inclinado por rechazar los recursos de inaplicabilidad consideran que tanto la restricción de carácter procesal como la de naturaleza material o sustantiva que subyacen a la prohibición del ne bis in idem son "en principio, restricciones que vinculan al sentenciador" 41 . Es el juez quien debe velar porque un mismo hecho no vuelva a ser juzgado o sancionado:

“(...) la prohibición del non bis in ídem tiene como destinatario de referencia normativa fundamental al juez sentenciador que, en el caso concreto, debe resolver si es que un hecho sometido a un procedimiento radicado en su competencia ya ha sido juzgado, siguiendo la regla clásica de coincidencia de sujetos, hecho y fundamento, o, si el comportamiento que ha de ser juzgado se describe y sanciona en diversas disposiciones sin fundamento para ello (prohibición de doble valoración)"42.

En relación con el legislador, en cambio, se insiste en la idea de que tiene libertad para definir el delito, los bienes jurídicos que pretende tutelar y las sanciones a imponer, las que incluso pueden ser varias:

"El legislador en materia penal tiene libertad para definir los bienes jurídicos que pretende cautelar mediante la sanción punitiva. Por tanto, es perfectamente admisible que una conducta pueda infringir diversos bienes jurídicos generando una multiplicidad de penas. Así las posibilidades sancionatorias son amplias y muchas veces el legislador podrá concurrir, legítimamente, a fijar penas principales, penas accesorias, penas penales junto a sanciones administrativas o consecuencias no penales derivadas o anudadas a una pena penal" 43 .

“(...) para que haya vulneración a este principio, es necesario que un mismo ilícito, sea sancionado dos veces. Lo que se busca con este principio es evitar una doble valoración de una misma contravención. Pero este principio no prohíbe que una persona pueda ser castigada con dos sanciones por una misma infracción (STC Rol N ${ }^{\circ} 2402 / 2013$ ). Así, por ejemplo, un ilícito puede tener una pena principal y una pena accesoria" ${ }^{4}$.

De este modo, se comparte un argumento planteado por la doctrina que parte del dato cierto de que en la legislación penal es habitual que para una misma infracción se estipulen dos penas, sea en una misma disposición (penas copulativas) o en varias disposiciones dentro de

\footnotetext{
41 Voto por rechazar, disidente, STC 2045, considerando 38 ${ }^{\circ}$, seguido de una extensa cita de un informe del profesor Mañalich. Se repite en los votos por rechazar, considerandos $11^{\circ}$ y $12^{\circ}$, SSTC Rol N 1960,2108 y 2236; considerando $17^{\circ}$ SSTC Rol No 2402 y 2403; y voto disidente STC Rol No 3000 , considerando $13^{\circ}$.

${ }^{42}$ Voto por rechazar, disidente, STC 2045, considerando $40^{\circ}$; voto en empate, considerando $13^{\circ}$ SSTC Rol N $^{\circ}$ 1960, 2108 y 2236; y voto de mayoría, considerando $19^{\circ}$ SSTC Rol No 2402 y 2403 . Se afirma incluso que "es el juez sentenciador, por regla general, y no esta Magistratura, el que debe utilizar las herramientas de solución que el legislador le otorga para evitar juzgar o sancionar dos veces a una persona por un mismo hecho, si es que en el caso concreto se da tal hipótesis" (el destacado es nuestro), STC Rol N 1960, voto por rechazar, considerando $18^{\circ}$. Lo peculiar, en ese caso, es que el requerimiento ante el TC había sido planteado precisamente por el Juez de Policía Local que debía imponer las sanciones.

${ }^{43}$ Voto por rechazar, disidente, STC Rol No 2045, considerando 44º de mayoría, SSTC Rol No 2402 y 2403 , considerando $23^{\circ}$, y en empate SSTC Rol No $1960,1961,2018,2108$ y 2236, considerando $17^{\circ}$ en todas ellas. ${ }^{44}$ Voto por rechazar el requerimiento, STC 2346, 16 de enero de 2014, considerando $56^{\circ}$.
} 
un mismo sistema (penas accesorias), sin que se considere infringido el principio ne bis in idem en la medida en que no exista una doble valoración de un mismo hecho o circunstancia, sino que, más bien, la doble pena sea la medida que expresa de modo completo el desvalor asignado por el legislador a la infracción cometida. A partir de lo anterior se concluye que si es admisible la duplicidad de sanciones cuando han de ser impuestas por un mismo órgano, también serían admisibles si su imposición corresponde a órganos diversos, pues ese aspecto -la diversificación orgánica- sería enteramente irrelevante frente a una prohibición de punición múltiple ${ }^{45}$.

Desde esta posición en el Tribunal Constitucional se concede que el ne bis in idem impondría como única limitación para el legislador la prohibición de establecer penas crueles, inhumanas o degradantes; aunque no se llega a especificar qué se entiende por tales ni por qué se asocia ese principio con esta interdicción ${ }^{46}$.

En cambio, no cabría duda de que el principio que sí obliga al legislador es el de proporcionalidad, junto a la prohibición de exceso que de él deriva. Se dice que:

"el principio non bis in idem vincula al legislador al prohibirle establecer penas crueles, inhumanas o degradantes, abriéndole un campo material y formal de decisión bastante amplio para definir, determinar y disponer comportamientos valorados negativamente y el establecimiento de penas proporcionales asociadas a dicho comportamiento, mientras no excedan ese baremo y mientras los sentenciadores dispongan de los mecanismos para evitar que una persona se vea doblemente sancionada y/o juzgada por el (los) mismo(s) fundamento(s) y hecho(s). En este sentido, la libertad reconocida al legislador, dentro de estos parámetros, es vasta y debe presumirse" ${ }^{47}$.

\section{Posibilidad de superposición de normas: concursos}

Para resolver esta polémica debemos partir por precisar un aspecto en el que, en realidad, están todos de acuerdo: el principio ne bis in idem no prohíbe que un mismo hecho esté tipificado y asociado a una sanción en más de un precepto. Los supuestos de superposición de normas sancionadoras no son per se contrarios a esta garantía ${ }^{48}$, mientras no den lugar a

\footnotetext{
${ }^{45}$ En ese sentido MAÑALICH, "El principio ne bis in idem frente a la superposición”, cit. nota n 9 , p. 559 y HERNÁNDEZ BASUALTO, Héctor, "Actividad administrativa, procedimiento sancionatorio-administrativo y proceso penal: algunas necesidades de coordinación legal”, en: ARANCIBIA MATTAR, Jaime; ALARCÓN JAÑA, Pablo (coords.), Sanciones Administrativas. X Jornadas de Derecho Administrativo, Asociación de Derecho Administrativo, Santiago: Thomson Reuters, 2014, pp. 571-572.

${ }^{46}$ Esto último es cuestionable: aunque dos sanciones, en conjunto, pueden significar un trato cruel, inhumano o degradante, ese efecto lo puede tener, también, una única sanción.

${ }^{47}$ STC Rol No 2045, voto disidente de rechazo, considerando $41^{\text {o }}$; voto de mayoría SSTC Rol No 2402 y 2403 , considerando $20^{\circ}$; y en empate SSTC Rol No $1960,1961,2018,2108$ y 2236, considerando $14^{\circ}$ en todas ellas.

${ }^{48}$ La Corte Interamericana de Derechos Humanos ha llevado la garantía más allá, afirmando que dos leyes son incompatibles con el artículo 8.4 de la Convención Americana, por referirse a conductas no estrictamente delimitadas, por lo que podrían ser comprendidas indistintamente dentro de un delito como de otro: Corte IDH, serie C, número 33, caso Loayza Tamayo vs. Perú, sentencia de 17 de septiembre de 1997, párrafo 68. Dicho
} 
OSSANDÓN, Magdalena. "El legislador y el principio ne bis in idem".

más de una sanción o a más de un proceso por los mismos hechos y con idéntico fundamento ${ }^{49}$.

En realidad, este no es un fenómeno extraño ni patológico dentro del ordenamiento jurídico, sino que puede considerarse, más bien, como una consecuencia inevitable de la abstracción del tipo ${ }^{50}$. Una característica del sistema que puede ser incluso necesaria para la adecuada regulación de las conductas prohibidas.

Así, al interior del sistema penal, un mismo hecho puede ser subsumible en varios tipos penales que lo sancionen en atención a diversos o al mismo fundamento, dando lugar a un concurso ideal de delitos o a un concurso aparente de leyes penales respectivamente.

\subsection{Concurso ideal de delitos}

Cuando el hecho es subsumible en diversos tipos penales pero cada uno de ellos lo sanciona en atención a fundamentos diferentes, estaremos ante infracciones diversas y, por lo mismo, todas ellas deben ser consideradas. Es lo que se conoce como un concurso ideal de delitos que, de conformidad con lo dispuesto en el artículo $75 \mathrm{CP}$, es sancionado aplicando la pena mayor del delito más grave.

Esta regla de penalidad atenuada es apreciada por una parte de la doctrina, precisamente, como expresión del ne bis in idem. En efecto, se afirma que al existir una cierta identidad de hecho- habría que reconocer un efecto parcial del principio, a fin de evitar una doble valoración negativa de los elementos coincidentes ${ }^{51}$. No es que se postule que la figura del concurso ideal sea en sí misma contraria al principio ne bis in idem, sino que "la prohibición de la doble valoración de unas mismas circunstancias de hecho exige el mantenimiento del concurso ideal con un régimen penológico más benigno que el del concurso real"52.

De conformidad con esta visión, entonces, cabría concluir que el ne bis in idem sí impone una exigencia directa al legislador, pues le obligaría a configurar un régimen penológico especial para el concurso ideal de delitos, que tome en cuenta que concurre un solo hecho que no debe ser valorado en forma duplicada. En consecuencia, al legislador le estaría vedado

comentario resulta, a todas luces, excesivo, considerando también el escueto reconocimiento que la Convención hace del principio ne bis in idem.

${ }^{49}$ Cfr. DE LEÓN VILLALBA, Acumulación, cit. nota n ${ }^{\circ}$ 7, p. 411; GARCÍA ALBERO, Non bis in idem, cit. nota $n^{\circ} 31$, p. 79; NIETO GARCÍA, Derecho Administrativo Sancionador, cit. nota no 10, p. 486; ALARCÓN SOTOMAYOR, Lucía, La garantía "non bis in idem” y el procedimiento administrativo sancionador, Madrid: Iustel, 2008, p. 58, n. 60 y OTTAVIANO, La garantía, cit. nota n 4, p. 95.

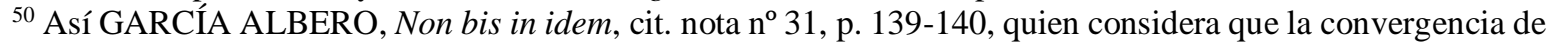
normas es un coste estructural de todo ordenamiento jurídico.

${ }^{51}$ Cfr. CUERDA RIEZU, "El concurso de delitos", cit. nota n ${ }^{\circ}$ 30, pp. 835-836, con referencias a PUPPE, ldealkonkurrenz und Einzelverbrechen, 1979, pp. 19 y ss., 55 y 303. También NIETO GARCÍA, Derecho Administrativo Sancionador, cit. nota $\mathrm{n}^{\circ} 10$, p. 519.

${ }^{52}$ CUERDA RIEZU, “El concurso de delitos”, cit. nota no 30, p. 849. 
adoptar un "sistema de pena unitaria", es decir, un sistema en que el concurso ideal y el concurso real queden sometidos a idéntico tratamiento penológico ${ }^{53}$.

Frente a esta tesis, otra parte de la doctrina considera que el principio ne bis in idem cede en estos casos en favor de la exigencia de realizar una íntegra valoración jurídica del hecho; en virtud del "mandato de exhaustividad" la sentencia condenatoria ha de abarcar todo el contenido de ilicitud del comportamiento ${ }^{54}$. En otras palabras, el principio ne bis in idem prohíbe incurrir en una duplicidad de valoraciones, pero no a costa de omitir la consideración de una parte del contenido de ilicitud de una de las infracciones concurrentes.

Más precisamente y en estricto rigor, el ne bis in idem no sería operativo en las hipótesis de concurso ideal por faltar uno de sus presupuestos, esto es, la identidad de fundamento ${ }^{55}$ : aunque se impusieran las sanciones correspondientes a cada una de las infracciones, no se estaría sancionando lo mismo. Si es que se adopta un régimen de penalidad menos severo que el de la simple acumulación es, acaso ${ }^{56}$, por razones de proporcionalidad, para que el castigo sea adecuado a la conducta valorada en su conjunto ${ }^{57}$, pero no directamente en virtud de la prohibición de doble valoración.

Esta variedad de opiniones radica en una diversa comprensión del principio, la que tiene su origen, fundamentalmente, en qué es lo que se tiene en cuanta al analizar la eventual "duplicidad": si la extensión o la intensión del tipo penal ${ }^{58}$. La distinción entre estos aspectos proviene de la lingüística ${ }^{59}$, en que por intensión de una palabra se entiende la referencia al conjunto de caracteres o propiedades que conforman su significado, es decir, el sentido de esa expresión. La extensión, en tanto, comprende todos y cada uno de los objetos a que la palabra se aplica. Ambas referencias están en recíproca relación, aunque la primera es la preponderante, en el sentido de que ella determina la extensión del término ${ }^{60}$.

${ }^{53}$ CUERDA RIEZU, “El concurso de delitos", cit. nota n ${ }^{\circ} 30, \mathrm{pp} .849-850$ parte de la idea de que siempre y por definición el concurso ideal representa un menor contenido de injusto que el concurso real porque existe un mismo hecho común a varios tipos de injusto. Por lo tanto, al fijar su régimen penológico el legislador se tendrá que "mover necesariamente entre dos extremos: puede ser superior a la pena prevista para la unidad de delito y debe ser inferior al sistema de penalidad regulado para el concurso real".

${ }^{54}$ GARCÍA ALBERO, Non bis in idem, cit. nota no 31, p. 239 y MAÑALICH, "El principio", cit. nota no 2, p. 143.

${ }^{55}$ En este sentido ALARCÓN, La garantía "non bis in idem”, cit. nota no 49, p. 77; CANO CAMPOS, Tomás, "Non bis in idem, prevalencia de la vía penal y teoría de los concursos en el derecho administrativo sancionador", Revista de Administración Pública, N ${ }^{\circ} 156$ (2001), pp. 191-249, pp. 244-246; DE LEÓN VILLALBA, Acumulación, cit. nota n 7, pp. 494 y 498; PÉREZ MANZANO, La prohibición, cit. nota n 3, p. 121 y MAÑALCH, "El principio", cit. nota n ${ }^{\circ}$, p. 154.

56 Según MAÑALICH, "El principio", cit. nota n 2, p. 154 la cuestión del régimen punitivo aplicable al concurso ideal no depende del alcance de la prohibición de punición múltiple.

${ }^{57}$ ALARCÓN, La garantía “non bis in idem”, cit. nota n' 49, p. 77.

${ }^{58}$ Propone recurrir a esta distinción PUPPE, Idealkonkurrenz und Einzelverbrechen, 1979, p. 72, idea que es recogida por GARCÍA ALBERO, Non bis in idem, cit. nota n 31, p. 234 y ss. También MAÑALICH, "El principio", cit. nota $\mathrm{n}^{\mathrm{o}} 2$, p. 151.

${ }^{59}$ Sobre esto vid. OSSANDÓN WIDOW, M. Magdalena, La formulación de tipos penales. Valoración crítica de los instrumentos de técnica legislativa, Santiago: Ed. Jurídica de Chile, 2009, pp. 63-64.

${ }^{60}$ Vid. ITURRALDE SESMA, Victoria, Lenguaje legal y sistema jurídico, Madrid: Tecnos, 1989, p. 32. 
En relación con el tipo penal, la intensión alude a la cualidad del comportamiento en tanto lesivo o peligroso para un determinado bien jurídico; mientras que su extensión abarca todo el universo de comportamientos que han recaído o podrán recaer en el futuro bajo el tipo en cuestión.

Pues bien, decíamos que algunos estiman que la presencia de un único hecho en el concurso ideal implica un cierto grado de identidad que debe ser tomado en cuenta para rebajar la penalidad aplicable. Para esta posición, el ne bis in idem prohíbe considerar varias veces los elementos fácticos que se requieren para afirmar la concurrencia de cada infracción; por lo tanto, al existir identidad fáctica, no se podría pretender aplicar la penalidad completa de todas las infracciones concurrentes. De este modo, se está poniendo el acento en la extensión del tipo penal, en los hechos, en la conducta concreta subsumible en cada tipo

Pero respecto de esta posición se pueden plantear ciertos reparos. En primer lugar, porque supone que la realización de una sola conducta o hecho necesariamente significa un menor injusto, razón por la cual debería operar un sistema de penalidad atenuada ${ }^{61}$; sin embargo, eso no tiene por qué ser así. Siguiendo el ejemplo propuesto por García Albero, no parece menos injusta "la conducta del padre que lanza el cochecito en el que están sus hijos gemelos puente abajo, que la de quien, con menos sentido práctico y en la misma situación, procede a tirarlos individualmente" 62 ; tampoco parece que sea menos grave provocar la muerte de varias personas haciendo detonar un elemento explosivo, mecanismo especialmente peligroso y dañino, que hacerlo disparando contra cada una de ellas ${ }^{63}$.

Algo de esto se trasluce en el esfuerzo que hace parte de la doctrina por negar la aplicabilidad de la regla del art. $75 \mathrm{CP}$ a los supuestos de concurso ideal homogéneo referidos a bienes personalísimos, por la vía de considerar que en estos casos, aunque el acto material sea único, normativamente habría varias acciones, "tantas como finalidades típicas existan y bienes jurídicos personales resultan afectados"64.

\footnotetext{
${ }^{61}$ En ese sentido CUERDA RIEZU, “El concurso de delitos”, cit. nota n ${ }^{\text {o } 30, ~ p . ~ 849, ~ a u n q u e ~ s u ~ a r g u m e n t a c i o ́ n ~}$ es circular cuando dice: "el concurso ideal representa siempre y por definición un menor contenido de injusto que el concurso real, en cuanto que una misma acción o hecho es común a varios tipos de injusto y en consecuencia no puede ser valorado varias veces en la determinación de la pena, porque lo impide el non bis in idem y el principio de proporcionalidad".

${ }^{62}$ GARCÍA ALBERO, Non bis in idem, cit. nota no 31, p. 239.

${ }^{63}$ Cfr. NOVOA, Eduardo, Curso de Derecho penal chileno. Parte general, $3^{\mathrm{a}}$ ed., Santiago: Ed. Jurídica de Chile, 2005, p. 267

${ }^{64}$ GARRIDO MONTT, Mario, El homicidio y sus figuras penales, $2^{\text {a }}$ ed., Santiago: Ed. Jurídica Conosur, 1994, p. 348. Similar NOVOA, Curso, cit. nota no 63, p. 232. En doctrina española, por todos, MIR PUIG, Santiago, Derecho penal. Parte general, $7^{\mathrm{a}}$ ed., $2^{\mathrm{a}}$ reimpr., Montevideo-Buenos Aires: BdeF, 2005, L 27/42. Ahora bien, como hace ver MAÑALCH, "El principio", cit. nota $n^{\circ} 2$, pp. 154-155, de aceptarse esa argumentación ella debería valer por igual frente a todo concurso ideal, homogéneo o heterogéneo, entre delitos de resultado, lo que supone restringir los supuestos de concurso ideal -o de aplicabilidad de la regla del art. $75 \mathrm{CP}$ - únicamente a los casos en que un solo hecho constituya dos o más delitos de mera actividad. Solución coherente con las premisas pero que no parece compartida por quienes las defienden.
} 
Por otra parte, si el argumento de que el ne bis in idem prohíbe una "duplicidad o pluralidad de efectos jurídicos (el bis) sobre un mismo sustrato real (el idem)"65 es llevado al extremo, debería invocarse también cuando existe identidad en el sujeto que realiza la conducta. Entonces habría que concluir que la regla penológica de la reiteración de delitos sería una expresión del mismo principio, por lo que debería tener alcance general y no limitado únicamente a los delitos de la misma especie ${ }^{66}$; algo que no parece ser defendido por nadie.

Quienes niegan que la reducción de la pena prevista para el concurso ideal responda a la prohibición de doble valoración, analizan la aplicabilidad del principio en conexión con una interpretación intensional de los tipos penales. Desde este punto de vista, lo relevante es que la descripción típica contiene los elementos que fundamentan el injusto, es decir, la lesión o puesta en peligro de un bien jurídico. Que un homicidio sea realizado por un disparo no supone que el hecho de disparar sea, en sí mismo, desvalorado. Un disparo, en tanto mera conducta fáctica, puede tener muy diversos significados - desde un saludo militar a una conducta homicida-, pero para efectos penales lo relevante son las cualidades que hacen del disparo una conducta prohibida. En relación con esas cualidades es que se determina la penalidad correspondiente, de lo que se sigue que "las descripciones de las conductas típicas aparecen, en relación con los marcos penales que las conminan, en un contexto intensional"67. En otras palabras, el mero hecho fáctico es valorativamente neutro, mientras que la sanción se determina en función de la valoración de las características o cualidades jurídicopenalmente relevantes de ese hecho. Por lo tanto, como bien explica García Albero, la prohibición de sancionar dos veces por lo mismo o, más exactamente, de valorar dos veces lo mismo, no opera en el ámbito "de la mera identidad total o parcial del concreto hecho subyacente, sino en el de su valoración jurídica. Y no podría ser de otra forma: el non bis in idem no se pronuncia sobre sus presupuestos, sino que simplemente toma aquéllos que son jurídicamente relevantes". En definitiva, el principio se configura a partir de la valoración jurídica que del hecho hacen las normas sancionadoras por lesionar o poner en peligro un bien jurídico ${ }^{68}$.

Desde esta perspectiva, el ne bis in idem no obliga al legislador a estipular un régimen especial más benigno para el concurso ideal de delitos. Pero ello no se debe a que la

\footnotetext{
${ }^{65}$ CUERDA RIEZU, “El concurso de delitos”, cit. nota $n^{\circ} 30$, p. 845.

${ }^{66}$ Conclusión a la que debería llevar, también, la tesis tradicional de que el régimen de excepción para la reiteración de delitos de la misma especie responde al principio de humanidad. Por el contrario, el que la morigeración del sistema penológico contemplada en el art. $351 \mathrm{CPP}$ se restringa únicamente a los delitos de la misma especie obliga a buscar un fundamento diferente. Cfr. CONTRERAS GUERRERO, Pablo, "Una tesis para entender la medida de la pena en los casos de reiteración de delitos de la misma especie: análisis de las reglas penológicas contenidas en el artículo 351 del Código Procesal Penal a la luz del Principio de Proporcionalidad Constitucional”, Polít. Crim., Vol. 9, № 18 (2014), A10, pp. 614-667, pp. 616 y 630 ; de acuerdo con la crítica MAÑALICH, Juan Pablo, "La reiteración de hechos punibles como concurso real. Sobre la conmensurabilidad típica de los hechos concurrentes como criterio de determinación de la pena", Polít. Crim, Vol. 10, N 20 (2015) A3, pp. 498-527, p. 510.

${ }^{67}$ GARCÍA ALBERO, Non bis in idem, cit. nota $\mathrm{n}^{\circ} 31$, p. 238.

${ }^{68}$ Tal como lo considera CANO CAMPOS, “Non bis in idem”, cit. nota n ${ }^{\circ} 55$, pp. 245 para defender su posición.
} 
OSSANDÓN, Magdalena. "El legislador y el principio ne bis in idem".

prohibición de punición múltiple no le sea vinculante ${ }^{69}$, sino porque la aplicación de la penalidad completa de cada una de las infracciones cometidas por medio del mismo hecho no contradice este principio.

\subsection{Concurso aparente de leyes penales}

Es posible que concurran diversos tipos penales para sancionar un mismo hecho, coincidiendo el fundamento de la punición en todos ellos. Cuando esto ocurre estamos ante un concurso aparente de leyes penales, el que no resulta proscrito por el ne bis in idem en relación con su tipificación abstracta, sino únicamente en cuanto a la posibilidad de imponer las diversas penas concurrentes. Y esto ocurre, precisamente, porque el concurso aparente supone una coincidencia en la valoración jurídica del hecho. Entonces, si con un disparo se provoca la muerte de una persona con la que se tiene una relación de filiación, el hecho es subsumible tanto en el tipo de parricidio como en el de homicidio simple; pero en ambos tipos penales se valora la misma cualidad de la conducta en tanto homicida, por lo que no pueden ser aplicados conjuntamente.

En consecuencia, a pesar de que concurren dos o más realizaciones típicas, la pena deberá determinarse de conformidad con una sola de ellas, en la medida en que, por valorar y sancionar lo mismo, la penalidad prevista en una norma -habrá que comprobar cuál- expresa de modo suficiente y adecuado el desvalor de todo el hecho juzgado.

Partimos aquí de una concepción del concurso aparente como un problema de determinación de la pena, que supone que el hecho está realmente incluido en el ámbito de previsión de las distintas normas, es decir, en que efectivamente se realizan los tipos penales concurrentes, pero bastaría con atender a uno para fijar la pena ${ }^{70}$. Es en este contexto en que tiene sentido

\footnotetext{
${ }^{69}$ MAÑALICH, "El principio", cit. nota ${ }^{\circ} 2$, pp. 153-154, asocia ambos argumentos, con un razonamiento que termina siendo circular: "la adopción de un régimen punitivo más favorable para los casos de concurrencia de realizaciones típicas en unidad de hecho - esto es, para los casos de concurso ideal- es una determinación que el legislador ciertamente puede hacer suya, pero que en ningún caso está obligado a hacer suya. Y puesto que todo concurso ideal es, en efecto, un concurso de delitos cuyos respectivos contenidos de ilicitud son recíprocamente independientes - pues de lo contrario habría que afirmar, más bien, un concurso aparente-, la cuestión se encuentra fuera del alcance del principio ne bis in idem. Lo cual quiere decir: la pregunta acerca de cuál ha de ser el régimen punitivo aplicable en casos de concurso ideal, en comparación con aquel aplicable en casos de concurso real, no depende del alcance de la prohibición de punición múltiple, desde ya porque se trata aquí de una determinación legislativa, en circunstancias de que la prohibición de punición múltiple no es vinculante para el legislador".

${ }^{70}$ Así lo concibe MAÑALICH, Juan Pablo, "El concurso de delitos: bases para su reconstrucción en el Derecho penal de Puerto Rico", Revista Jurídica de la Universidad de Puerto Rico, No 74 (2005), pp. 1021-1211, p. 499500, afirma que en el concurso aparente "lo que se excluye son las consecuencias de la afirmación de un concurso. En rigor, no es el tipo de delito que es inaplicable; más bien, es preterida la norma de sanción que establece ese supuesto de hecho como condición de la aplicación de la consecuencia punitiva respectiva", y que "la apariencia del concurso no es más que una metáfora que expresa que la agravación del marco penal en tales casos resulta excesiva". También MATUS, Jean Pierre, "La teoría del concurso (aparente) de leyes en la dogmática alemana, desde sus orígenes hasta el presente (primera parte)", Ius et praxis, vol. 6, N² (2000), pp. 295-371, p. 295 y ss. y PRAMBS, Claudio, “¿Es posible sancionar las lesiones y el homicidio en concurso
} 
apelar al ne bis in idem para prohibir la imposición conjunta de las sanciones previstas en cada una de las disposiciones.

No ocurre igual si se concibe esta clase de concurso, como hace buena parte de la doctrina en nuestro país, como un problema de interpretación de la ley en el sentido de que, si bien a primera vista son aplicables las distintas disposiciones penales, en realidad solo una rige el caso, quedando las otras totalmente desplazadas ${ }^{71}$. En el fondo, según esta concepción "el contenido positivo de la norma prevalente se incorporaría tácitamente como elemento negativo del tipo en la norma preterida" 72 . De este modo, el contenido de injusto de cada infracción no solo es diferente sino de mutua exclusión, sin intersección entre ellos.

Esto es lo que sucede, por ejemplo, cuando se define el homicidio simple como "matar a otro sin que concurran las condiciones especiales constitutivas del parricidio, infanticidio u homicidio calificado" 73 . Entonces, cuando concurren las características de las figuras de parricidio, infanticidio u homicidio calificado, el delito de homicidio simple no se configuraría por no verificarse su elemento negativo. Entre el homicidio simple y las demás figuras de homicidio existiría, entonces, una relación de mutua exclusión: se configura un delito o el otro, pero un hecho nunca podría satisfacer ambas descripciones típicas.

Si las disposiciones penales que aparentemente concurren en el mismo supuesto en realidad no concurren -se entiende que la norma preterida, en realidad, no contenía el hecho en cuestión- la apelación al principio ne bis in idem resulta superflua, pues se estaría invocando para resolver un problema que en realidad no existe ${ }^{74}$. Tal vez podría decirse que dicho principio opera más bien en un plano abstracto, previo, al impedir que un mismo hecho pueda ser considerado simultáneamente subsumible en más de una norma jurídica ${ }^{75}$. Se le haría

ideal?", Revista de Derecho de la Pontificia Universidad Católica de Valparaíso, XXXIV (2010), pp. 459-474, p. 461.

${ }^{71}$ Doctrina predominante en nuestro país luego de la obra de ETCHEBERRY, El concurso aparente de leyes penales, Santiago, s/f, según advierte MATUS, "La teoría“, cit. nota no 70, p. 295. Además de ETCHEBERRY, Derecho penal. PG, II, cit. nota $\mathrm{n}^{\circ}$ 5, pp. 122 y ss., así lo conciben BULLEMORE, Vivian; MACKINNON, John, Curso de Derecho Penal, Tomo II, Santiago: LexisNexis, 2005, p. 85; CURY URZÚA, Enrique, Derecho Penal. Parte General, $8^{\mathrm{a}}$ ed., Santiago: Ediciones Universidad Católica de Chile, 2005, p. 667; GARRIDO MONTT, Derecho penal. PG, II, cit. nota N 5, p. 456; LABATUT, Gustavo, Derecho penal, Tomo I, $9^{\mathrm{a}}$ ed. actualizada por Zenteno Vargas, reimpresión, Santiago: Ed. Jurídica de Chile, 2007, p. 174 y NOVOA, Curso, II, cit. nota $\mathrm{n}^{\circ}$ 64, p. 247.

${ }^{72}$ GARCÍA ALBERO, Non bis in idem, cit. nota $\mathrm{n}^{\circ}$ 31, p. 212.

${ }^{73}$ POLITOFF, Sergio; GRISOLÍA, Francisco; BUSTOS, Juan, Derecho Penal Chileno. Parte Especial, $2^{\mathrm{a}}$ ed., Santiago: Ed. Jurídica Congreso, 2006, p. 57; en el mismo sentido BULLEMORE, Vivian; MACKINNON, John, Curso de Derecho penal, $2^{\mathrm{a}}$ ed., Tomo III, Santiago: Legal Publishing, 2009, p. 11; ETCHEBERRY, Derecho penal. PG, III, cit. nota $\mathrm{n}^{\circ}$ 5, p. 23; GARRIDO MONTT, El homicidio, cit. nota ${ }^{\circ}$ 64, pp. 18-19;

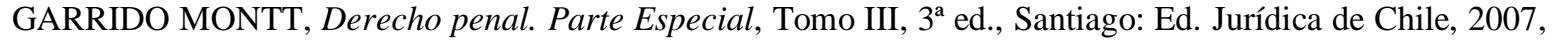
p. 22.

${ }^{74}$ Cfr. GARCÍA ALBERO, Non bis in idem, cit. nota $\mathrm{n}^{\text {o }} 31$, p. 139.

${ }^{75}$ Cfr. GARCÍA ALBERO, Non bis in idem, cit. nota $n^{\circ} 31$, p. 227. 
OSSANDÓN, Magdalena. "El legislador y el principio ne bis in idem".

operar, en el fondo, como un criterio de interpretación sistemática que reclama suponer elementos negativos tácitos en algunos tipos, a fin de asegurar la consistencia del sistema.

Aunque esta noción sobre el concurso aparente de leyes penales supone una construcción perfectamente consistente del ordenamiento jurídico ${ }^{76}$, genera varios problemas dogmáticos que la hacen inviable para adoptar soluciones coherentes en distintos aspectos de la teoría del delito.

Así, en primer lugar, esta forma de concebir la tipicidad de las figuras como excluyentes entre sí provoca dificultades para el tratamiento del error y la participación que no siempre son advertidos ni se condicen con la forma en que la doctrina aborda esos temas ${ }^{77}$.

Volviendo al ejemplo del homicidio simple, si este se concibe con una doble fase: una positiva, que consiste en matar a otro (aspecto que coincide con el esquema rector común a todas las figuras de este grupo) y otra negativa, que implica la ausencia de las diversas circunstancias propias de otras figuras ${ }^{78}$, ya no podría plantearse como la figura básica de todos los tipos de homicidio, pese a lo cual se sigue considerando como tal ${ }^{79}$.

En relación con la participación, por ejemplo, cuando junto al intraneus en un delito de parricidio concurre un cómplice que no tenga con la víctima alguno de los vínculos propios de ese delito, usualmente se estima que debería ser juzgado como cómplice de homicidio simple ${ }^{80}$, sin cuestionar la concurrencia de dicha figura pese a que, según esta misma doctrina, ella sería necesaria.

Por otra parte, si fuéramos consecuentes con las premisas de esta posición, frente a la hipótesis de alguien que crea equivocadamente que está matando a un pariente comprendido en la descripción del art. $390 \mathrm{CP}$, pero que en realidad no fuera tal ${ }^{81}$, habría que concluir que no cometería parricidio (objetivamente), pero tampoco homicidio simple (subjetivamente), pues si la expresión "en cualquier otro caso" con que se

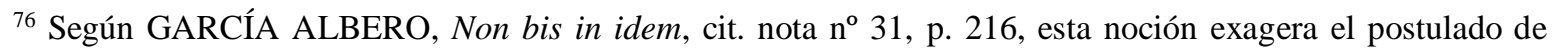
consistencia del ordenamiento jurídico.

${ }^{77}$ Discordancia denunciada entre nosotros por POLITOFF, Sergio; MATUS, Jean Pierre; RAMÍREZ, María Cecilia, Lecciones de Derecho Penal chileno. Parte Especial, $2^{\mathrm{a}}$ ed., Santiago: Ed. Jurídica de Chile, 2005, pp. 23-24. Especialmente lúcido en el análisis sobre estos problemas PEÑARANDA RAMOS, Enrique, Concurso de leyes, error y participación en el delito, Madrid: Civitas, 1991, pp. 31 ss., 181 ss.

${ }^{78}$ GARRIDO MONTT, El homicidio, cit. nota n ${ }^{\circ}$ 64, p. 18 y ETCHEBERRY, Derecho penal. PG, III, cit. nota $\mathrm{n}^{\circ} 5$, p. 23.

${ }^{79}$ Aunque Etcheberry cuida no incurrir en esa confusión, otros sí lo hacen. Vgr. GARRIDO MONTT, Derecho penal. PE, III, cit. nota $\mathrm{n}^{\mathrm{o}} 73$, p. 19 y 21.

${ }^{80}$ NOVOA, Curso, II, cit. nota $n^{\circ}$ 64, p. 216; GARRIDO MONTT, Derecho penal. PE, III, cit. nota $\mathrm{n}^{\mathrm{o}} 73$, p. 83 en el caso de que el extranues de un parricidio ignore la existencia de un vínculo de parentesco con el autor (de lo contrario le imputa parricidio); BULLEMORE / MACKINNON, Curso, cit. nota no 73, p. 36; CURY, Derecho Penal. PG, cit. nota ${ }^{\circ}$ 71, pp. 643-648; ETCHEBERRY, Derecho penal. PG, II, cit. nota $n^{\circ} 5$, p. 74; LABATUT, Derecho penal, cit. nota n ${ }^{\circ}$ 71, p. 196; POLITOFF / GRISOLÍA / BUSTOS, Derecho Penal Chileno. PE, cit. nota $\mathrm{n}^{\circ} 73$, p. 144.

${ }^{81}$ Caso destacado por POLITOFF / MATUS / RAMÍREZ, Lecciones. PE, cit. nota no 77, p. 24 , n. 8.
} 
describe esta última figura tiene un contenido típico, éste debe ser abarcado por el dolo del autor, cuestión que en el ejemplo queda descartada.

Otro aspecto negativo de esta concepción es que cuando se parte de la idea de una delimitación recíproca de las normas en principio concurrentes, queda absolutamente excluido cualquier recurso al precepto desplazado. No queremos aludir con esto a la posibilidad de combinación de los marcos penales, defendida mayoritariamente en Alemania, pero de un modo que se explica dentro de su particular sistema de determinación de la pena que es difícilmente trasladable a nuestro ordenamiento. Pero sí a otros posibles efectos. Por ejemplo, la posibilidad de aplicar el precepto desplazado "en caso de que deje de ser aplicable el precepto preferente pero no el desplazado" 82 .

Las consideraciones anteriores nos llevan a concluir que tiene más sentido y es más coherente con el tenor literal de los tipos, estimar que en el concurso aparente de leyes penales concurren efectivamente los diversos delitos porque el hecho es subsumible en cada una de las descripciones típicas ${ }^{83}$. Pero, en la medida en que en los diversos tipos concurrentes se realice un juicio de desvalor sobre la misma cualidad del hecho, ese juicio no puede considerarse doblemente. García Albero afirma que "más allá de la adecuación formal de una conducta a los diversos tipos delictivos implicados, la posibilidad de valorar aquélla conforme a todos éstos se sujeta a una condición evidente: no es lícito reiterar un idéntico juicio de desvalor sobre un único hecho. A idéntica valoración, sólo la pluralidad de hechos posibilita la pluralidad de valoraciones, y por tanto de infracciones" 84 . Y agrega que "en la medida en que la ley preterida no contiene ningún punto de vista valorativo que no esté implícita o explícitamente presente en la prevalente, hay que conceder que la aplicación de ésta última agota la relevancia jurídica del hecho en relación con su autor, despojándolo de su aptitud para soportar otra ulterior $-\mathrm{y}$ ya expresada- desvaloración" 85 .

En consecuencia, pese a que existe una pluralidad de realizaciones típicas y que la conducta efectivamente infringe las diversas normas en concurso, no se podría considerar que estamos ante una pluralidad de delitos porque estaríamos haciendo "valoraciones repetidas" sobre lo

\footnotetext{
${ }^{82}$ MIR PUIG, Derecho penal. $P G$, cit. nota $n^{\circ}$ 64, p. 647, aludiendo a diversas hipótesis: que el precepto preferente sea derogado, amnistiado o indultado; que exista una tentativa cualificada desistida respeto del delito preferente; que falte el dolo respeto de algún elemento del delito preferente o que no pueda ser aplicado por razones procesales.

${ }^{83}$ Respecto del homicidio simple, entendemos que la expresión final que emplea el legislador en el $\mathrm{N}^{\mathrm{o}} 2$ del artículo 391 debe interpretarse como la referencia explícita a una regla concursal, de subsidiaridad expresa, en sintonía con lo que establece el $\mathrm{N}^{\circ} 1$ del mismo artículo respecto del artículo $390 \mathrm{CP}$. En otras palabras, la mención "en cualquier otro caso" dice relación con la posibilidad de imponer la pena que ese numeral establece y no con las características típicas de la figura. A este respecto, cabe advertir que el rol dogmático que se le asigna a una expresión legal no puede estar determinada únicamente por la cuestión formal de que aparezca en la descripción legislativa, pues la ley puede contener menciones que no estén referidas a elementos típicos. Sobre esto, en general, OSSANDÓN, La formulación, cit. nota $n^{\circ}$ 59, § 141 ss, p. 130.

${ }^{84}$ GARCÍA ALBERO, Non bis in idem, cit. nota $n^{\circ} 31$, p. 217.

${ }^{85}$ GARCÍA ALBERO, Non bis in idem, cit. nota $n^{\circ} 31$, p. 218.
} 
OSSANDÓN, Magdalena. "El legislador y el principio ne bis in idem".

mismo. Como dice Jakobs, estamos ante un único delito pero que aparece formulado varias veces en la ley, aunque, quizá, en distintos grados de concreción ${ }^{86}$.

Esta duplicidad de valoraciones ha de juzgarse de conformidad con el concepto de injusto que se tenga como punto de partida, el que en nuestra opinión debe considerar el injusto objetivo tanto desde una perspectiva ex ante (el riesgo para el bien jurídico concretamente protegido estimado desde una dimensión cuantitativa y cualitativa, así como el riesgo previsible para otros bienes) como ex post (la medida efectiva de la lesión o puesta en peligro y de la negación de la norma ${ }^{87}$.

En definitiva, podemos concluir que el reconocimiento de un concurso aparente entre varias leyes constituye una manifestación del principio ne bis in idem en sentido sustancial ${ }^{88}$. Pero eso supone, al mismo tiempo, reconocer que este principio no prohíbe la multiplicidad de formulaciones coincidentes sobre un mismo supuesto de hecho, sino únicamente la reiteración de idénticos juicios de valoración al determinar la sanción aplicable.

\subsection{Superposición de disposiciones penales y administrativas}

La superposición de normas que sancionan un mismo hecho no solo se presenta hacia el interior del sistema penal, sino que también puede darse entre disposiciones penales y administrativas, fenómeno cada vez más frecuente en el Derecho penal moderno y dentro de éste, en el Derecho penal económico.

En este ámbito tampoco puede afirmarse que el ne bis in idem proscriba de entrada la existencia de esa duplicidad normativa, la que puede estar plenamente justificada en cada contexto específico. Generalmente eso ocurre cuando se decide sancionar penalmente una conducta que es parte de una actividad previa y necesariamente regulada en el ámbito administrativo. La gravedad del hecho puede ameritar su tipificación como delito sin que ello suponga una exigencia de derogar ilícitos administrativos con los que puede coincidir, total o parcialmente, desde el punto de vista de su sustrato fáctico; ilícitos que pueden ser parte fundamental del entramado de la regulación administrativa. Lo que resulta discutido es si puede sancionarse por ambas infracciones conjuntamente, aspecto sobre el cual volveremos más adelante.

Por ahora debemos volver a la pregunta inicial, esto es, si el ne bis in idem resulta vinculante para el legislador. Pues aun admitida la libertad de la que éste goza para tipificar doblemente un mismo hecho, cabe preguntarse si del principio emana alguna otra restricción respecto de las decisiones legislativas que es legítimo adoptar.

\footnotetext{
${ }^{86}$ JAKOBS, Günther, Derecho penal. Parte General. Fundamentos y teoría de la imputación, $2^{\mathrm{a}}$ ed., Trad. CUELLO CONTRERAS; SERRANO GONZÁLEZ DE MURILLO, Madrid: Marcial Pons, 1997, pp. 10481049.

${ }^{87}$ Seguimos el modelo para la cuantificación del injusto objetivo propuesto por SILVA SÁNCHEZ, Jesús María, "La teoría de la determinación de la pena como sistema (dogmático): un primer esbozo", InDret, 2/2007, pp. 11-13.

${ }^{88}$ GARCÍA ALBERO, Non bis in idem, cit. nota $\mathrm{n}^{\mathrm{o}}$ 31, p.
} 
Polit. crim. Vol. 13, № 26 (Diciembre 2018) Art. 8, pp. 952-1002.

[http://www.politicacriminal.cl/Vol_13/n_26/Vol13N26A8.pdf]

\section{Desvanecimiento de la regla}

Como decíamos, buena parte de la doctrina estima que el ne bis in idem no es vinculante para el legislador, sino que obliga únicamente al adjudicador. Si atendemos a su formulación usual, en efecto, lo que el ne bis in idem prohíbe es sancionar o juzgar dos veces por lo mismo, conductas que atañen precisamente al juez.

Respecto del legislador, según esta misma posición doctrinal, no habría más límite que el que emana del principio de proporcionalidad. Él tendría plena libertad para disponer la imposición de varias sanciones respecto de una misma conducta, como ocurre continuamente en nuestra legislación cada vez que en un tipo penal contempla la imposición conjunta de una pena privativa de libertad y una pena pecuniaria, o por la posibilidad de imponer la pena principal y las accesorias. Si ello no genera reparos al interior del sistema penal, se afirma, no habría obstáculo para que el legislador pudiera hacerlo también a través de disposiciones pertenecientes a distintos sectores del ordenamiento jurídico y, por tanto, aplicables por diversos órganos ${ }^{89}$. La única limitación -en la medida en que sea aplicable- sería que la reacción sancionatoria no sea desproporcionada.

Si el legislador tiene libertad para disponer esa duplicidad de sanciones, porque según su propia representación con ello se expresa adecuadamente la magnitud del merecimiento de pena que corresponde atribuir al hecho ${ }^{90}$, entonces resulta obvio que el juez tendrá que aplicar conjuntamente las normas de sanción concurrentes, incluso en el evento en que se pueda reconocer que entre el antecedente de imposición de la sanción penal y el antecedente de imposición de la sanción administrativa existe "una superposición total o parcial desde el punto de vista de sus respectivos contenidos de ilicitud" 91 . Las sanciones podrían aplicarse conjuntamente en la medida en que sean congruentes con el juicio valorativo del legislador; de ahí que "baste con un indicador suficientemente fuerte de que la acumulación de tales sanciones es congruente con esa representación legislativa para que decaiga una objeción susceptible de ser apoyada en el principio ne bis in idem"92.

\footnotetext{
${ }^{89}$ En ese sentido MAÑALICH, "El principio ne bis in idem frente a la superposición”, cit. nota n ${ }^{\circ}$ 9, p. 559, afirma que "si ello vale para el caso en que fuera un mismo órgano el habilitado para imponer conjuntamente dos sanciones de diversa naturaleza al responsable de un único hecho dotado de determinada significación delictiva, entonces ello también ha de valer para el caso en que sean dos órganos diferentes los habilitados para imponer una y otra sanción por separado". También HERNÁNDEZ, “Actividad administrativa", cit. nota n 45, pp. 571-572: “¿Por qué el legislador que puede disponer legítimamente la imposición simultánea de varias penas no puede prever la imposición conjunta de penas y sanciones administrativas sólo porque para ello deben actuar distintos órganos competentes? En términos absolutos no se aprecia ninguna justificación razonable".

${ }^{90}$ MAÑALICH, "El principio ne bis in idem frente a la superposición”, cit. nota no 9, p. 549.

${ }^{91}$ MAÑALICH, "El principio ne bis in idem frente a la superposición”, cit. nota n 9, p. 558.

${ }^{92}$ MAÑALICH, "El principio ne bis in idem frente a la superposición”, cit. nota $n^{\circ}$ 9, p. 559. Anteriormente, el mismo autor había sido un poco menos exigente: "si hay base suficiente para atribuir al legislador la sobrevaloración de una misma propiedad de determinado hecho, entonces esa sobrevaloración no es prima facie interpretable como redundancia, sino como énfasis en su valoración negativa", MAÑALICH, "El principio", cit. nota $n^{\circ} 2$, p. 143 .
} 
Incluso podría llegar a afirmarse la regla en sentido inverso: solo si existen antecedentes o indicadores de que la acumulación de sanciones contradice o excede la representación legislativa cabría objetar su imposición conjunta. Porque si el legislador ha dispuesto esa variedad de sanciones, solo cabría oponerse a su imposición cuando su aplicación conjunta sobrepase la medida de una respuesta proporcionada a la gravedad de la infracción cometida. De no superar ese límite, la duplicidad de sanciones habría de verse como la forma en que el legislador -en el marco de libertad que se le reconoce- ha desvalorado la conducta ${ }^{93}$.

Sin embargo, estamos de acuerdo con Cano Campos cuando concluye que "esta concepción del non bis in idem conduciría realmente [...] a su propia desaparición"94. En efecto, la prohibición sería todavía aplicable a supuestos bastante obvios y limitados, impidiendo la aplicación reiterada de un mismo precepto respecto de un mismo hecho; pero en estos casos ni siquiera es indispensable invocar esta prohibición pues basta con constatar la infracción del principio de legalidad: la doble sanción contradice lo que establece la propia ley en la que basa el pronunciamiento, según la cual corresponde aplicar una determinada sanción ${ }^{95}$.

Para otros supuestos en que existan diversas disposiciones - penales o administrativas-, que se refieran a un mismo hecho, el ne bis in idem en sentido sustantivo perdería sentido como regla, debiendo ser reemplazado por el estudio de la representación legislativa para determinar la medida de la valoración y, en consecuencia, la posibilidad o no de imponer dos sanciones. En otras palabras, no sería suficiente argumentar que no se va a aplicar una determinada sanción porque ello infringe la prohibición de doble valoración, sino que el argumento debería ser que aplicar las dos sanciones contradice o excede el juicio de desvalor legislativo, el que solo está restringido por el principio de proporcionalidad.

La conclusión anterior sería aplicable en diversos ámbitos, permitiendo imponer una duplicidad de sanciones a un sujeto respecto de un mismo hecho y con el mismo fundamento, en relación con $i$ ) un único tipo penal (según lo estipulan expresamente las disposiciones del Código penal que disponen sanciones copulativas o accesorias), ii) dos o más tipos penales, iii) un tipo penal y uno administrativo, y $i v$ ) varias infracciones administrativas.

El caso de concurrencia de varios tipos penales que coincidan en la sanción de un hecho con el mismo fundamento podría sorprender, pues se refiere a los supuestos de concursos aparentes de leyes penales. Pero si se interpreta el principio ne bis in idem tal como venimos exponiendo, no se ve cómo podría servir de argumento para impedir la aplicación de todas las sanciones si eso se considera congruente con la representación legislativa y no resulta desproporcionado.

Con esto pretendemos demostrar que si la prohibición de punición múltiple no alcanza de algún modo al legislador, pierde utilidad también a la hora de interpretar y aplicar las normas

\footnotetext{
93 "Si la doble sanción no resulta arbitraria y desproporcionada tampoco afectaría al principio" dice ARROYO, "Principio de legalidad", cit. nota n 30, p. 19. En el mismo sentido MAÑALICH, "El principio ne bis in idem", cit. nota $\mathrm{n}^{\circ} 9$, pp. 558-559.

${ }^{94}$ CANO CAMPOS, “Non bis in idem”, cit. nota $\mathrm{n}^{\circ} 55$, p. 208.

95 Aplicarla dos veces no es más que un error aritmético y, en ese sentido, lógico, dice MAÑALICH, "El principio", cit. nota $\mathrm{n}^{\mathrm{o}} 2$, p. 142.
} 
Polit. crim. Vol. 13, № 26 (Diciembre 2018) Art. 8, pp. 952-1002.

[http://www.politicacriminal.cl/Vol_13/n_26/Vol13N26A8.pdf]

penales. Si el juez debe imponer todas las sanciones en la medida en que ello sea conforme con la valoración que el legislador ha realizado - o si se quiere, en la medida en que no se pueda argumentar que sea disconforme con esa valoración-, entonces el principio ne bis in idem no tiene nada que aportar en sí mismo y no obligaría a la hora de adjudicar responsabilidad penal. El juez tendría que revisar caso a caso: si la segunda sanción supone un énfasis en la valoración, deberá aplicarla; si aparece como redundante, deberá considerar suficiente la primera. Pero entonces, el hecho de no aplicar las dos sanciones no será una consecuencia del ne bis in idem, sino que respondería únicamente a consideraciones sobre proporcionalidad y legalidad.

De este modo, el ne bis in idem desaparece como regla y no representa ni siquiera un criterio de interpretación que pueda ofrecer algo diferente a lo que se sigue de las consideraciones de proporcionalidad, porque ya no existiría la prohibición de valorar dos veces ni imponer dos sanciones, sin más, sino de realizar una doble valoración que permita imponer dos sanciones que en conjunto signifiquen una respuesta punitiva desproporcionada. Un ejemplo de lo anterior lo aporta el mismo Mañalich cuando propone interpretar el art. $351 \mathrm{CPP}$ como un régimen de exasperación de la pena global obtenida por vía de unificación ficticia de los dos o más hechos punibles concurrentes. Frente a la objeción de que esa solución vulneraría el principio ne bis in idem por considerar en dos ocasiones un mismo hecho (el número de delitos cometido) en un sentido perjudicial para el imputado ${ }^{96}$, argumenta que ella

"desconoce que, en cuanto estándar sustantivo de adjudicación penal, el principio ne bis in idem no vincula al legislador, sino al respectivo órgano jurisdiccional en el ejercicio de su potestad de aplicación de la legislación. Bajo el principio ne bis in idem en su estatus de prohibición de sobrevaloración, el tribunal debe abstenerse de dar una aplicación redundante a las reglas que fijan presupuestos de fundamentación e intensificación de la pena. Pero la detección de semejante redundancia se ve excluida allí donde la sobrevaloración debe ser interpretada, más bien, como un énfasis legislativo en la relevancia penológica de uno o más factores determinados. Con ello, la pregunta por el carácter eventualmente excesivo de tal énfasis no es una que pueda ser respondida a través de una invocación del principio ne bis in idem, sino sólo a través de una aplicación argumentativamente no del todo controlable- del principio de proporcionalidad". ${ }^{97}$

Por otra parte, si el único límite es el de la proporcionalidad, en la práctica no existen mayores posibilidades de control respecto de la decisión legislativa sobre las sanciones a imponer y

\footnotetext{
${ }^{96}$ Primero para determinar el marco penal tenido como base para calcular el aumento de pena y, luego, en la magnitud de dicho aumento. Objeción compartida por CONTRERAS GUERRERO, "Una tesis" p. 653; COUSO SALAS, Jaime, "Comentario previo a los Arts. 74 y 75. El régimen concursal en el derecho chileno. Tratamiento doctrinario y jurisprudencial”, en COUSO / HERNÁNDEZ (dir.), Código penal comentado. Parte General. Doctrina y jurisprudencia, Santiago: Abeledo Perrot - Legal Publishing, 2011, p. 648 y OLIVER CALDERÓN, Guillermo, "La exasperación de la pena en el concurso material de delitos: la reiteración de delitos de la misma especie", Revista de Derecho (Valdivia), vol. XXVI, No 2 (2013), pp. 167-188, pp. 173174.

${ }^{97}$ MAÑALICH, “La reiteración”, cit. nota n 66, pp. 519-520.
} 
su gravedad $^{98}$. Porque el principio de proporcionalidad, si bien tiene una gran fuerza como centro de argumentación jurídica, no permite emitir juicios claros para los casos concretos, salvo los evidentes ${ }^{99}$. En general, no cabe sino reconocer que "cuando se trata de la concreta norma penal a juzgar, no es posible apreciar una infracción" 100 , porque "el principio de proporcionalidad caracteriza más un deseo dirigido al legislador racional que una garantía comprobable y jurídicamente vinculante en la decisión para el caso singular" ${ }^{\prime 101}$.

Esto repercute, a su vez, en la posibilidad de controlar la aplicación judicial, pues solo sería posible objetar la imposición de varias sanciones si se comprueba que se está haciendo una aplicación redundante o reiterada de un juicio de desvalor del legislador, no por la mera aplicación de la prohibición de punición múltiple. En la medida en que resulte difícil conocer con precisión cuál sea esa valoración legislativa y cuándo una segunda sanción puede considerarse desproporcionada, se priva al juez de los elementos necesarios para una aplicación segura y estable de la ley.

Llegados a este punto, nos parece que para resolver sobre el alcance del principio ne bis in idem en su vertiente sustantiva es necesario volver la mirada sobre los fundamentos en que se apoya.

\section{Más allá de las exigencias de proporcionalidad: seguridad jurídica}

Se han planteado diversos fundamentos respecto del ne bis in idem en sentido sustantivo que van desde la cosa juzgada, el principio de legalidad, la interdicción de arbitrariedad, consideraciones de justicia, el respeto por la dignidad humana, etc. ${ }^{102}$. Con todo, ha ido imponiéndose paulatinamente la posición que asocia la prohibición de sancionar doblemente con el principio de proporcionalidad ${ }^{103}$, o con mayor precisión, con la prohibición de exceso que deriva aquel. Ciertamente, la imposición de varios castigos por un mismo ilícito tiende a mostrarse como excesiva y, por tanto, desproporcionada.

\footnotetext{
${ }^{98}$ Lo reconoce MAÑALCH, "La reiteración”, cit. nota $n^{\circ}$ 66, p. 510.

99 HASSEMER, Winfred, "El principio de proporcionalidad como límite de las intervenciones jurídicopenales", Trad. CASTIÑEIRA PALOU, M. Teresa; ROBLES PLANAS, Ricardo, en: VON HIRSCH, Andrew / SEELMAN, Kurt / WOHLERS, Wolfgang (ed. alemana); ROBLES PLANAS, Ricardo (ed. española) Límites al Derecho penal. Principios operativos en la fundamentación del castigo, Barcelona: Atelier, 2012, p. 198.

100 NEUMANN, Ulfrid, "El principio de proporcionalidad como principio limitador de la pena", Trad. SÁNCHEZ-OSTIZ, Pablo, en: VON HIRSCH / SEELMAN / WOHLERS (ed. alemana); ROBLES PLANAS (ed. española) Límites al Derecho penal. Principios operativos en la fundamentación del castigo, Barcelona: Atelier, 2012, pp. 202-203. En el mismo sentido GARCÍA ALBERO, Non bis in idem, cit. nota n 31 , p. 88.

${ }^{101}$ NEUMANN, "El principio", cit. nota no 100, p. 203; por lo que advierte que "el alcance de la prerrogativa de decisión que el Tribunal Constitucional concede al legislador para la introducción y definición de tipificaciones ha tendido a ensancharse -sub especie del principio de proporcionalidad-, hasta acabar haciendo de la legislación penal un ámbito libre jurídico-constitucional”.

102 Un buen resumen de la diversidad de posiciones en ALARCÓN, La garantía "non bis in idem", cit. nota n" 49 , pp. 23-28.

${ }^{103}$ Opinión que prevalece en nuestra jurisprudencia (vid. supra n. 18 y 19) y en la doctrina más reciente, así MAÑALICH, "El principio", cit. nota no 2, p. 142, EL MISMO (2014) p. 548 y PIÑA, Juan Ignacio, Derecho penal. Fundamentos de la responsabilidad, Santiago: Abeledo Perrot- Legal Publishing, 2010, p. 257
} 
Pero cabe preguntarse si se trata solo de un problema de proporcionalidad. Pues si así fuera, no debería existir mayor cuestionamiento a la hora de imponer dos sanciones que, en conjunto, no superen el umbral del máximo permitido por el legislador en una de las disposiciones concurrentes ${ }^{104}$. En el fondo, como hemos dicho, la prohibición no sería la de imponer dos sanciones, sin más, sino de imponer dos sanciones que en conjunto signifiquen una respuesta punitiva desproporcionada. Pero, como hemos visto, esto implica que la regla del ne bis in idem pierde sentido y debería ser reemplazada por un juicio, en cada caso concreto y con las dificultades que ello implica, relativo a la proporcionalidad de las sanciones en el marco de la representación valorativa del legislador.

El reconocimiento del ne bis in idem como una regla con valor propio, por el contrario, supone que su fundamento no radique únicamente en ideas de proporcionalidad, sino que también en consideraciones relacionadas con la seguridad jurídica.

Consideramos, en efecto, que el ne bis in idem es una regla ${ }^{105}$, pues goza de las características que distinguen a las reglas en contraposición con los principios: concretan cuáles son los supuestos de hecho a los que se refieren, operan para casos concretos, no admiten aplicación gradual y operan por subsunción, no por ponderación ${ }^{106}$. En tanto regla, consiste en un "enunciado normativo derivado de la ponderación entre dos o más principios, con pretensiones de aplicación a un grupo de casos" ${ }^{107}$. En concreto, la prohibición de sancionar dos veces por lo mismo se encuentra ligada a consideraciones tanto de proporcionalidad como de seguridad jurídica, perspectiva desde la cual se conecta también con el principio de legalidad ${ }^{108}$.

${ }^{104}$ Lo hace notar OTTAVIANO, La garantía, cit. nota no 4, p. 121 y lo defiende expresamente ARROYO, "Principio de legalidad", cit. nota $n^{\circ}$ 30, p. 19: "si la doble sanción no resulta arbitraria y desproporcionada tampoco afectaría al principio". El mismo argumento sustenta la posición del Tribunal Constitucional español en la STC 2/2003, de 16 de enero, en que se declara que, atendido que en el caso concreto el tribunal penal realizó una compensación, descontando de la sanción penal lo que había sido ya sancionado administrativamente, el recurrente no había sufrido exceso punitivo alguno. Es también uno de los argumentos del voto de disidencia en la STC 3000-16, 10 de enero de 2017, para rechazar la inaplicabilidad solicitada: " $E l$ artículo 207 literal a) le permitía al Juez de Policía Local imponerle 45 días de suspensión por cada una de ellas. En los hechos, se le aplicaron multas que acumularon 20 días de suspensión. No deja de ser paradójico que constituya una hipotética vulneración al principio non bis in ídem que puedan sumárseles 45 y hasta 90 días más en circunstancias que ese pudo ser el monto completo de las suspensiones si se aplicaran en el máximo, atendida la reiteración de conductas", considerando $39^{\circ}$ voto disidente.

105 De esta opinión, por ejemplo, HERNÁNDEZ, "Actividad administrativa", cit. nota n $\mathrm{n}^{\mathrm{o}} 45$, p. 572 y SÁNCHEZ-OSTIZ GUTIÉRREZ, Pablo, Fundamentos de Política criminal. Un retorno a los principios, Madrid: Marcial Pons, 2012, p. 68. En cambio, lo consideran principio, DE LEÓN VILLALBA, Acumulación, cit. nota $\mathrm{n}^{\circ}$ 7, p. 376-378; MUÑOZ CLARES, Ne bis in idem, cit. nota ${ }^{\circ}$ 7, p. 269; OTTAVIANO, La garantía, cit. nota $\mathrm{n}^{\circ} 4$, p. 141.

${ }^{106}$ Cfr. SÁNCHEZ-OSTIZ, Fundamentos, cit. nota no 105, p. 54, pp. 67 y ss.

107 SÁNCHEZ-OSTIZ, Fundamentos, cit. nota nº 105, p. 68.

${ }^{108}$ Le atribuyen este doble fundamento BOLDOVA PASAMAR, Miguel Ángel, "Los principios del Derecho penal", en: ROMEO CASABONA, Carlos María; SOLA RECHE, Esteban y BOLDOVA PASAMAR, Miguel Ángel (coords.), Derecho penal. Parte general, Granada: Comares, 2013, p. 39; DE LEÓN VILLALBA, "Sobre 
Dicha vinculación con el principio de legalidad no alude a una derivación directa, en la línea de la jurisprudencia inicial del Tribunal Constitucional español ${ }^{109}$, sino que a la legalidad en tanto que ella misma está conectada con la proporcionalidad, porque esta última ha de resultar de la valoración legislativa plasmada en el precepto penal.

El Tribunal Constitucional español lo explica ahora en los siguientes términos:

"La garantía material de no ser sometido a bis in idem sancionador, que, como hemos dicho, está vinculada a los principios de tipicidad y legalidad de las infracciones (...), tiene como finalidad evitar una reacción punitiva desproporcionada (...), en cuanto dicho exceso punitivo hace quebrar la garantía del ciudadano de previsibilidad de las sanciones, pues la suma de la pluralidad de sanciones crea una sanción ajena al juicio de proporcionalidad realizado por el legislador y materializa la imposición de una sanción no prevista legalmente" 110 .

Para explicar mejor el punto conviene que repasemos ciertas consideraciones básicas relativas al principio de legalidad y al concepto de seguridad jurídica.

Partimos de la base de que el principio de legalidad tiene como fundamento la pretensión de garantizar la libertad de los individuos mediante un sistema penal que evite la arbitrariedad

el sentido", p. 18, cit. nota n 10; DÍAZ Y GARCÍA CONLLEDO, Miguel, "Ne bis in idem material y procesal”, Revista de Derecho, Universidad Centroamericana, N 9 (2004), p. 10; MUÑOZ LORENTE, José, La nueva configuración del principio non bis in idem (Las sanciones administrativas como límite a la intervención de la jurisdicción penal. Especial referencia al ámbito ambiental), Madrid: Ed. La Ley, 2001, pp. 52-54; NIETO MARTÍN, Adán, El principio de ne bis in idem en el Derecho penal europeo e internacional, en: ARROYO ZAPATERO, Luis; NIETO MARTÍN, Adán (coord.), El principio de ne bis in idem en el Derecho penal europeo e internacional, Cuenca, Ediciones de la Universidad Castilla-La Mancha, 2007, pp. 10-11. Por su parte, LÓPEZ, El principio”, cit. nota n ${ }^{\circ}$, p. 59, plantea la posibilidad de que el principio de seguridad jurídica sea el fundamento último de la prohibición de doble sanción en todo caso; en términos similares también CARPIO BRIZ, David, "Europeización y reconstitución del non bis in idem", en: MIR PUIG, Santiago; CORCOY BIDASOLO, Mirentxu (dirs.), Constitución y sistema penal, Madrid: Marcial Pons, 1989, p. 241. Se refieren solo a la legalidad (con la proporcionalidad como consecuencia), HORMAZÁBAL / BUSTOS, "Principio de legalidad", cit. nota n 30, p. 164 y ORTIZ QUIROGA, Luis; ARÉVALO CUNICH, Javier, Las consecuencias jurídicas del delito, Santiago: Ed. Jurídica de Chile, 2013, p. 106.

${ }^{109}$ Interpretación tan aplaudida - por permitir que el ne bis in idem sea reconocido como una garantía o, incluso, un derecho constitucional que hace procedente el recurso de amparo propio del sistema español-como cuestionada por lo forzada que resulta. Cfr. ALARCÓN, La garantía “non bis in idem”, cit. nota n 49, p. 28, quien indica que "el debate está viciado porque la conveniencia de configurarlo como un derecho fundamental susceptible de amparo hizo creer necesario conectarlo con el art. 25.1 de la Constitución y, por tanto, buscarle fundamento forzosamente en el principio de legalidad y tipicidad"; CANO CAMPOS, "Non bis in idem", cit. nota $\mathrm{n}^{\circ} 55$, p. 205; CUERDA RIEZU, "El concurso de delitos", cit. nota $\mathrm{n}^{\circ}$ 30, p. 846, la califica como una jurisprudencia "muy creativa"; y HUERTA TOCILDO, Susana, "El derecho fundamental a la legalidad penal”, Revista española de Derecho Constitucional, Año 13, No 39 (1993), p. 101, afirma que la incorporación del ne bis in idem en el derecho subjetivo de la legalidad penal ha ocurrido "por obra y gracia de una interpretación integradora".

${ }^{110}$ STC 2/2003, de 16 de enero, fundamento jurídico $3^{\circ}$. 
Polit. crim. Vol. 13, № 26 (Diciembre 2018) Art. 8, pp. 952-1002.

[http://www.politicacriminal.cl/Vol_13/n_26/Vol13N26A8.pdf]

estatal y garantice la objetividad ${ }^{111}$. La idea de seguridad jurídica se refiere precisamente a eso; consiste en la "cualidad del ordenamiento que produce certeza y confianza en el ciudadano sobre lo que es derecho en cada momento y sobre lo que previsiblemente lo será en el futuro" 112 .

Esto significa que la seguridad jurídica se manifiesta, en consecuencia y en primer lugar, como una "exigencia objetiva de regularidad estructural y funcional del sistema jurídico a través de sus normas e instituciones"113. El aspecto estructural se refiere a la garantía de una disposición y formulación regular de las normas e instituciones integradoras del sistema jurídico. La corrección funcional, en tanto, comporta la garantía del cumplimiento del Derecho por todos sus destinatarios y de regularidad de actuación de los órganos encargados de su aplicación; porque la realización del Derecho es la que garantiza la libertad ${ }^{114}$.

Pero, además, la seguridad jurídica presenta una dimensión subjetiva o de certeza, que consiste en la proyección de las garantías estructurales y funcionales en las situaciones personales, y se traduce en la posibilidad de conocimiento previo de las consecuencias jurídicas de los propios actos ${ }^{115}$.

Como decíamos, la necesidad de garantizar la libertad de los individuos mediante un sistema penal que evite la arbitrariedad estatal, fundamento del principio de legalidad, se relaciona directamente con la seguridad jurídica en sentido objetivo; lo que no se opone a reconocer que al garantizar esa seguridad objetiva se consiga también hacer previsibles y cognoscibles las reacciones estatales ${ }^{116}$.

Esta referencia a la seguridad jurídica en su dimensión objetiva funcional permite explicar mejor el concepto de legalidad positiva al que ha recurrido parte de la doctrina española cuando intenta fundamentar la relación del principio de legalidad con la prohibición de bis in idem. Aunque se considera que esta prohibición encuentra su fundamento último en consideraciones de proporcionalidad, dicha proporcionalidad debe ser expresada a través de una forma determinada, que garantice una mayor seguridad jurídica.

${ }^{111}$ Cfr. JAKOBS, Derecho penal, cit. nota $n^{\circ} 86$, §4/9, p. 82; MADRID CONESA, Fulgencio, La legalidad del delito, Valencia: Universidad de Valencia, 1983, p. 29 y VAN WEEZEL, Alex, La garantía de tipicidad en la Jurisprudencia del Tribunal Constitucional, Santiago: Abeledo Perrot-Thomson Reuters, 2011, p. 12.

112 SAINZ MORENO, Fernando, "Seguridad Jurídica”, en: MONTOYA MELGAR (dir.), Enciclopedia jurídica básica, tomo IV, Madrid: 1995, p. 6108.

113 PÉREZ LUÑO, Antonio-Enrique, La seguridad jurídica, Barcelona: Ariel, 1991, p. 21 (destacado en el original).

${ }^{114}$ Cfr. PÉREZ LUÑO, La seguridad, cit. nota n 113, pp. 23-26.

115 Sobre el concepto de seguridad jurídica y su extensión en dos dimensiones, MADRID CONESA, La legalidad, cit. nota $\mathrm{n}^{\circ} 111$, p. 14.

${ }^{116}$ Así se explica la referencia a la previsibilidad contenida en la cita que acabamos de hacer a la STC español $2 / 2003$. Ahora bien, en este sentido cabe destacar que el propio concepto de previsibilidad ha ido evolucionando en un sentido objetivo, de cognoscibilidad de la ley; cfr. ROXIN, Claus, Teoría del tipo penal. Tipos abiertos y elementos del deber jurídico, Trad. BACIGALUPO ZAPATER, Buenos Aires: Depalma, 1979, p. 107. Para MADRID CONESA, La legalidad, cit. nota n 111, p. 13, esta objetivación del concepto termina por dejar de lado la misma idea de previsibilidad, y se corresponde más bien con la de protección frente a la arbitrariedad. 
OSSANDÓN, Magdalena. "El legislador y el principio ne bis in idem".

\section{Legalidad positiva}

García Albero propone fundamentar la prohibición de sancionar varias veces un mismo hecho en el principio de legalidad, sobre la base de que este principio se refiere tanto a la predeterminación de la conducta punible como de la sanción a imponer y cumple una función garantizadora respecto de cada uno de estos aspectos. Citando a Beling, advierte que "la adopción de normas penales específicas y su tipificación determina que «para los actos que yacen fuera de ellas no se dará punibilidad alguna, mientras que para aquellos otros que caen en su ámbito no se dará otra punibilidad distinta a la determinada en las normas específicas». Los tipos penales y/o administrativos no desempeñan pues, exclusivamente una función garantizadora negativa, determinando a contrario ámbitos de libertad, sino también positiva, asegurando que para los hechos en ellos subsumibles no han de producirse consecuencias diversas a las previstas [...] La sanción asignada a cada ilícito expresa el desvalor que el Ordenamiento jurídico atribuye a una determinada conducta, y se impone con pretensión de agotar tal desvalor. De ahí se infiere que la pretensión de volver a sancionar una ilicitud vulnere el principio de legalidad, pues supone, de modo indirecto, rebasar los límites de la sanción prefijados"117.

En otras palabras, se puede afirmar que la duplicidad de sanciones sobre el mismo ilícito resulta siempre desproporcionada, pues cuando el legislador describe una conducta y le asocia una determinada pena, se entiende que esta pena es adecuada al desvalor del injusto que conlleva el comportamiento ilícito, de modo que esa pena debe agotar ese desvalor ${ }^{118}$. La desproporción que lleva consigo la duplicidad de sanciones es "un efecto que trae causa de la previa infracción del principio de legalidad", o en términos más generales, "la proporcionalidad es un posterius respecto a la legalidad" ${ }^{119}$.

Ahora bien, para que tenga sentido esta dimensión de legalidad positiva, es necesario considerar la referencia a la ley o a la norma en toda su extensión como mensaje prescriptivo, sin identificarla únicamente con lo que se dice en un artículo determinado. Esto supone partir de la distinción entre la formulación de la norma, es decir, la expresión lingüística que se

${ }^{117}$ GARCÍA ALBERO, Non bis in idem, cit. nota $n^{\circ}$ 31, pp. $82-83$ (destacado en el original). Esta posición es compartida por CANO CAMPOS, "Non bis in idem", cit. nota $\mathrm{n}^{\circ} 55$, p. 207, quien habla de una "funcionalidad excluyente del principio de legalidad”; CUBERO MARCOS, José Ignacio, El principio non bis in idem en la Ley vasca de la potestad sancionadora, Oñati, Instituto Vasco de Administración Pública, 2010, p. 36 y PÉREZ MANZANO, La prohibición, cit. nota n ${ }^{\text {3 } 3, ~ p . ~ 71-73 . ~}$

${ }^{118}$ De modo similar, OTTAVIANO, La garantía, cit. nota $n^{\circ}$ 4, p. 48 afirma que "como la sanción penal es la más grave del ordenamiento jurídico, seguramente quepa atribuirle el sentido de una respuesta integral a un buen número de finalidades legítimas que el Estado podría perseguir mediante la imposición de sanciones diversas a una misma persona por un cierto hecho".

${ }^{119}$ CUBERO MARCOS, El principio, cit. nota n ${ }^{\circ}$ 117, p. 40. En el mismo sentido GARCÍA ALBERO, Non bis in idem, cit. nota $\mathrm{n}^{\mathbf{0}} 31$, p. 89: "en la delimitación entre el efectivo concurso de normas sancionadoras y el mero conflicto, parece que la proporcionalidad por sí sola no puede jugar papel alguno, sino que tal tarea ha de realizarse con criterios lógicos y teleológicos que desvelen el solapamiento desvalorativo de ambos preceptos. Una vez afirmado y resuelto el conflicto, la vulneración del principio de legalidad antecede a la propia lesión del principio de proporcionalidad". 
utiliza para ello, y la norma o el significado de esa expresión ${ }^{120}$. Las expresiones lingüísticas pueden estar repartidas en distintas disposiciones o enunciados legales, todas las cuales concurren para completar la norma (sea norma de conducta o de sanción).

Así como es fácil reconocer que no todo enunciado legal expresa una norma jurídica completa (por ejemplo, las disposiciones del Libro I del Código penal, destinado a la parte general, no transmiten mensajes prescriptivos completos), "tampoco los preceptos definidores de los diferentes delitos determinan por sí solos todos los extremos de las normas penales, cada una de las cuales surge, pues, de la puesta en relación de varios enunciados legales" ${ }^{21}$. En lo que aquí interesa, las consecuencias jurídicas asociadas a la realización de una conducta típica pueden estar estipuladas en diversas disposiciones. Cuando el art. $391 \mathrm{~N}^{\circ}$ 2 sanciona al que mate a otro con presidio mayor en su grado medio, le asigna a su vez la pena de inhabilitación absoluta perpetua para cargos y oficios públicos y derechos políticos y la de inhabilitación absoluta para profesiones titulares mientras dure la condena (art. 28), la pérdida de los efectos que de provengan del delito y de los instrumentos con que se ejecutó (art. 31). El mensaje prescriptivo completo se construye con todos esos enunciados: la penalidad que corresponde a cada delito es la que se describe en cada tipo de la parte especial, además de las penas accesorias. Solo por razones de economía legislativa, el legislador no enumera todas esas penas en cada artículo de la parte especial, sino que hace una remisión general a través de las disposiciones de la parte general.

Pese a esta dispersión de enunciados o disposiciones, estamos ante una única norma de sanción que se plantea para el caso en que se infrinja la norma de conducta que subyace a ella. Tratándose de una única norma de sanción, no se vulnera el principio de legalidad tal como se encuentra estipulado en nuestra Constitución. Recordemos que en su artículo $19^{\circ}$ $\mathrm{N}^{\circ} 3$ inciso noveno dispone que: Ninguna ley podrá establecer penas sin que la conducta que se sanciona esté expresamente descrita en ella; es decir, que la conducta y la pena deben encontrarse vinculadas en una misma y única ley. Pero la referencia a la "ley" no alude a un único artículo; si así fuera estaríamos ante una exigencia exagerada y carente de justificación ${ }^{122}$.

\section{Ne bis in idem sustantivo como regla formal}

${ }^{120}$ Así, ALCHOURRÓN, Carlos; BULYGIN, Eugenio, "Norma jurídica”, en: GARZÓN VALDÉS, Ernesto; LAPORTA, Francisco (eds.), El derecho y la justicia, Madrid: Trotta, 1996, pp. 134-135 e ITURRALDE SESMA, Victoria, "Elementos semántico-sintácticos de indeterminación de los enunciados normativos en el lenguaje legal", Theoria, $2^{a}$ época, año III, no 7-8 (1988), pp. 157-190, p. 160.

${ }^{121}$ MIR PUIG, Derecho penal. PG, cit. nota $n^{\circ}$ 64, L 2/3, p. 71.

122 De este modo pierde sentido la crítica de MAÑALICH, "El principio ne bis in idem frente a la superposición", cit. nota $\mathrm{n}^{\circ}$ 9, p. 560, cuando dice que "si uno se tomara en serio el argumento favorable a esta supuesta función positiva del principio de legalidad, habría que concluir que la técnica legislativa consistente en habilitar la imposición de penas accesorias a través de cláusulas generales contenidas en reglas legales distintas de la norma de sanción que establece las respectivas penas principales, por dar un ejemplo, resultaría incompatible con el principio de legalidad. Lo cual muestra que el argumento de hecho no puede ser tomado en serio". 
OSSANDÓN, Magdalena. "El legislador y el principio ne bis in idem".

Recapitulando lo anterior, podemos decir que cuando el legislador tipifica una conducta, dimensiona su gravedad -tanto por el riesgo que genera como por la medida de la forma en que afecta el bien jurídico y de la negación de la norma que implica- y le asocia una pena que corresponde al desvalor que se asigna a la realización del comportamiento prohibido. Esto es exigencia del mismo principio de proporcionalidad, en cuanto requiere que la pena sea idónea para el fin al que se dirige, necesaria como la alternativa menos gravosa y en un razonable equilibrio con el contenido de ilicitud de la conducta prohibida (proporcionalidad en sentido estricto). Por lo tanto, cuando el legislador decide conminar la realización de una conducta con una sanción, debe procurar que dicha sanción sea el mínimo necesario para cumplir los objetivos perseguidos con la menor afectación posible de los derechos de los afectados. Si esto es así, establecer una nueva sanción basada en el mismo fundamento resultará necesariamente desproporcionado.

Sobre esta base, la regla del ne bis in idem sustantivo debería operar como el cierre del sistema, impidiendo que un hecho sea doblemente sancionado, con idéntico fundamento, por aplicación de dos normas de sanción distintas, aun cuando se argumente que así se completa el juicio de desvalor que corresponde asignar a la conducta prohibida y que la imposición de las dos sanciones no afectaría el juicio de proporcionalidad. Porque la prohibición de volver a sancionar una conducta no debe radicarse únicamente en consideraciones sobre proporcionalidad, sino que a ello se han de sumar las de seguridad jurídica.

Podría cuestionarse que exista realmente un problema mayor seguridad jurídica, pues la imposición de dos sanciones exigiría, de todos modos, que ellas estén previamente determinadas, de modo que la sanción final -la adición de ambas- sigue siendo previsible. La inseguridad operaría, a lo sumo, "hacia abajo", en la medida en que alguna de las sanciones podría no llegar a ser aplicada. Sin embargo, aun desde esta perspectiva, la existencia de distintas normas aplicables implica una mayor cuota de inseguridad, abre espacios a mayores posibilidades de arbitrariedad y se vincula a la contingencia de lo que puede ocurrir en cada proceso sancionatorio.

Por eso, la imposición de una segunda sanción habrá de resultar siempre prohibida, sin que dependa de un análisis particular relativo a la concreta relación de proporcionalidad entre las penas y la conducta desvalorada. Aunque eventualmente podría ocurrir que la acumulación de penas no sobrepase ese desvalor, por ejemplo, porque se han impuesto en sus rangos mínimos, igualmente el ne bis in idem prohíbe imponerlas todas.

De este modo, el ne bis in idem se configura como una regla formal que asegura la regularidad funcional en la aplicación de la ley sustrayéndola a la contingencia y a las diferencias interpretativas en su aplicación concreta.

Un claro ejemplo de esta funcionalidad del ne bis in idem lo encontramos en el artículo 63 del Código penal, que establece una regla que impide al juez conceder efecto alguno a las circunstancias agravantes en las hipótesis a que la norma se refiere, cerrando el espacio a cualquier argumentación sobre la proporcionalidad concreta que esta decisión pueda tener. La regla supone que el legislador ya ha debido valorar completamente la circunstancia agravante al tipificarla como delito, al expresarla al describir un delito determinado, e incluso -en la hipótesis menos vinculada con la previsión consciente del legislador-cuando se trate 
de una circunstancia inherente al delito. Aunque puedan existir indicadores fuertes en orden a que la aplicación de la agravante sería congruente con la representación legislativa sobre el desvalor de la conducta, igualmente está prohibido aplicarla. En consecuencia, si el legislador quiere valorar la relación de parentesco al sancionar un homicidio, deberá hacerlo completamente al determinar la pena del parricidio. Al juez le está vedada la posibilidad de sumar la desvaloración que comporta la circunstancia agravante en relación con el tipo de parricidio, aun cuando otros antecedentes indiquen que solo así abarcaría todo el desvalor que el legislador asigna a ese comportamiento.

Ahora bien, en el caso del artículo 63 del Código penal estamos frente a una disposición legal que obliga solo al juez, respecto de la cual es indiscutible que el propio legislador podría establecer excepciones. Pero cabe preguntarse si tiene sentido incorporar una disposición equivalente en un nivel superior -la Constitución o un tratado internacional-que obligue también al legislador ${ }^{123}$, o si debe interpretarse en ese sentido el reconocimiento que se hace de la garantía del ne bis in idem en tanto principio limitador del ius puniendi estatal basado en la protección de la dignidad de la persona en un Estado de Derecho ${ }^{124}$.

\section{Límite para el legislador}

Las consideraciones previas sobre la operatividad del ne bis in idem respecto del juez o adjudicador llevan a concluir que es el propio legislador quien debe evitar incurrir en duplicidad de valoraciones de lo mismo a través de distintas normas. Esto significa que cuando se prohíbe $\mathrm{u}$ ordena un determinado comportamiento, la pena asociada a su realización u omisión ha de ser la adecuada para agotar todo el desvalor de ese injusto típico, en atención al riesgo para el bien jurídico protegido, la medida en que se afecta dicho bien y en que se niega la norma, además de los elementos de la imputación subjetiva. Una sanción que corresponda con la gravedad del hecho, pero en el mínimo necesario para cumplir sus objetivos.

\subsection{Reconocimiento de esta limitación por el Tribunal Constitucional}

En la jurisprudencia de nuestro Tribunal Constitucional, pese a que han existido dos opiniones a la hora de enjuiciar la inaplicabilidad de ciertas disposiciones por infracción del principio ne bis in idem, podríamos decir que existe unanimidad al considerar que este principio implica un límite para el legislador, pues le prohíbe sancionar dos veces por "lo mismo". En realidad, para ser más precisos, no le prohíbe establecer dos normas

\footnotetext{
${ }^{123}$ Las Constituciones políticas que contienen una referencia explícita al ne bis in idem lo hacen en su dimensión procesal, no sustantiva. Así ocurre en el caso de Alemania, Colombia, Costa Rica, Estados Unidos y México. Lo propio puede decirse en relación con su consagración en tratados internacionales. En el Pacto de Derechos Civiles y Políticos, artículo $14 \mathrm{~N}^{\circ}$ 7, en la Convención Americana de Derechos Humanos de 1969, artículo 8 $\mathrm{N}^{\circ} 4$ (vid. supra 1), en el artículo 50 de la Carta Europea de Derechos Humanos y en el artículo $4^{\circ}$ del Protocolo 7 del Convenio Europeo de Derechos Humanos.

${ }^{124}$ Como afirma reiteradamente nuestro Tribunal Constitucional. Por todas, STC Rol No 3000,10 de enero de 2017, considerando $7^{\circ}$.
} 
OSSANDÓN, Magdalena. "El legislador y el principio ne bis in idem".

sancionatorias referidas a un mismo hecho y fundamento, pero sí pretender que sean aplicables, simultánea o sucesivamente, a un mismo sujeto.

En efecto, cuando se ha discutido el alcance del ne bis in idem en nuestro Tribunal Constitucional, quienes han defendido la posibilidad de imponer varias sanciones por un mismo hecho lo hacen insistiendo en que la libertad del legislador le permitiría fijar varias penas respecto de un mismo comportamiento, siempre que eso se haga en el marco de las exigencias de proporcionalidad y -se dice- siempre que el sistema proporcione los mecanismos para que el juez no llegue a sancionar dos veces por lo mismo ${ }^{125}$. Más todavía, la posibilidad de establecer varias sanciones, penales y administrativas, para un mismo comportamiento -según la opinión de los ministros que estamos comentando- está condicionada a que el comportamiento "infrinja diversos bienes jurídicos", y la argumentación entonces se ha centrado en mostrar que los bienes jurídicos son efectivamente diversos, lo que hace compatible la duplicidad de sanciones.

Por ejemplo, el artículo $4^{\circ}$ de la Ley $\mathrm{N}^{\circ} 19.886$, dispone que sean excluidos del Registro Oficial de Contratistas de la Administración a quienes "hayan sido condenados por prácticas antisindicales o infracción a los derechos fundamentales del trabajador, dentro de los anteriores dos años". Es decir, esta disposición permite que una persona que ya ha sido condenada por infringir los derechos fundamentales del trabajador, sea también sancionada con la prohibición de contratar con la Administración. Los ministros que votaron por declararla conforme con la Constitución afirmaban que había diversidad de fundamento en su imposición: una condena previa por un despido injustificado tiene como fundamento la necesidad de sancionar el atropello al trabajador, mientras que la exclusión del Registro Oficial de Contratistas constituiría una causa de inhabilidad debida a la falta de idoneidad para contratar con la Administración ${ }^{126}$.

Entonces, si cada infracción está referida a "diversos" bienes jurídicos, no existe identidad en el fundamento de las respectivas sanciones, y por eso podrían aplicarse conjuntamente. En otras palabras, las disposiciones enjuiciadas no resultan contrarias a la Constitución, pero no porque el legislador pueda disponer una doble sanción concurriendo la triple identidad de sujeto, hecho y fundamento, sino porque se consideró que en la especie no se daba esa triple identidad.

A contrario sensu, si esa triple identidad hubiera existido no se podrían establecer varias penas o, al menos, el legislador debería establecer los mecanismos para evitar que una persona sea doblemente sancionada o juzgada por el mismo fundamento y hecho.

\footnotetext{
125 "En todas las situaciones, habrá que estar al caso concreto de cautela de los bienes jurídicos protegidos, su proporcionalidad y su respeto a la interdicción de la doble incriminación por el triple fundamento de identidad en la persona, la conducta y sus fundamentos" concluyen las SSTC 2045, voto de minoría, considerando $44^{\circ}$ (el mismo en que reconocía la libertad del legislador para establecer multiplicidad de penas).

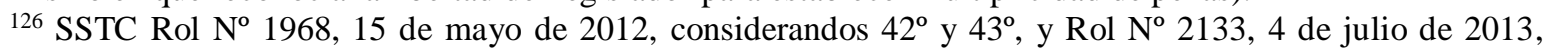
considerandos $27^{\circ}$ y $28^{\circ}$.
} 
Así se entiende mejor que desde esta misma posición por rechazar los recursos de inaplicabilidad, se cite la jurisprudencia de su par colombiano ${ }^{127}$, cuando afirma que el ne bis in idem

"no es sólo una prohibición dirigida a las autoridades judiciales (...) Una norma legal viola este derecho cuando permite que una persona sea juzgada o sancionada dos veces por los mismos hechos. Dicha permisión puede materializarse de diferentes formas, todas contrarias a la Constitución. De tal manera que la única forma en que el legislador viola dicho principio no se contrae a la autorización grosera de que quien hubiere sido absuelto en un juicio penal puede volver a ser juzgado exactamente por la misma conducta ante otro juez nacional cuando un fiscal así lo solicite, mediante una acusación fundada en el mismo expediente. El principio non bis in ídem, por lo menos, también prohíbe al legislador permitir que una misma persona sea objeto de múltiples sanciones, o juicios sucesivos, por los mismos hechos ante una misma jurisdicción"128.

De este modo, se está admitiendo un límite a la libertad del legislador, quien no puede pretender que se sancione dos veces a un mismo sujeto, por un mismo hecho y con idéntico fundamento. En otras palabras, el legislador queda también obligado por el ne bis in idem.

\subsection{Prohibición de "doble valoración" no de duplicidad de penas}

Como ya hemos advertido, es habitual que en la legislación penal se estipulen varias penas copulativas o accesorias- para una misma infracción, sin que se considere infringido el principio ne bis in idem ${ }^{129}$, pues este solo prohíbe la valoración múltiple respecto un mismo hecho para fundamentar más de una sanción ${ }^{130}$.

Más aún, la multiplicidad de penas está claramente permitida por nuestra Constitución, pues cuando el artículo $19 \mathrm{~N}^{\mathrm{o}} 3$ inciso noveno exige que la conducta que se sanciona esté expresamente descrita en la ley, lo hace en relación con la posibilidad de que ella establezca

127 En SSTC Rol No 1968, 15 de mayo de 2012, considerando 39; y Rol No 2133, 4 de julio de 2013 , considerando $25^{\circ}$, votos suscritos por los mismos, pero con otro ministro redactor.

${ }^{128}$ CC Colombia C-115-08, fundamento 4.1. La referencia a una misma jurisdicción implicaría restringir la aplicabilidad del principio exclusivamente al orden penal, pero aún en este ámbito se está reconociendo una limitación al legislador. Por otra parte, en la línea de la interpretación del Tribunal Europeo de Derechos Humanos (infra 9.3), puede estimarse que lo relevante es la naturaleza sustancialmente penal de las sanciones, más que su denominación o implementación formal. Así se evita que, por la vía de distinguir dos jurisdicciones distintas, opere un fraude de etiquetas que permita socavar la prohibición de bis in idem.

${ }^{129}$ De un modo especialmente exigente, BUSTOS RAMÍREZ, Juan; HORMAZÁBAL MALARÉE, Hernán, Lecciones de Derecho penal. Parte General, Madrid: Trotta, 2006, p. 96, llegan a cuestionar que se esté respetando el ne bis in idem cuando se recurre a penas accesorias, pues es necesario "considerar si una pena accesoria es realmente tal, o bien, por su gravedad, es la aplicación de una nueva pena al mismo hecho".

130 Más restrictivamente FIANDACA, Giovanni; MUSCO, Enzo, Derecho Penal. Parte general, Trad. FERNANDO NIÑO, Luis, Bogotá (Colombia), Ed. Temis, 2006, p. 677, consideran que el ne bis in idem sustancial [solo] "prohíbe atribuirle dos veces a un mismo autor un suceso valorable unitariamente desde el punto de vista normativo". 
penas, en plural, respecto de dicha conducta. Si bien esas penas han de estar contempladas en la ley-referencia en singular-, que describe la conducta.

Cuando existe un ilícito para el que se estipula una multiplicidad de sanciones, todas esas sanciones configuran, por así decirlo, la penalidad única que corresponde por la infracción cometida. Ello es así en la medida en que exista una única norma, un único juicio de desvalor que se expresa en esa variedad de penas que habrán de ser impuestas, necesariamente, en una única instancia procesal, a través de una única sentencia condenatoria. Por lo tanto, en este caso podemos afirmar que estamos frente a una norma sancionatoria, aunque ella pueda estar construida a través de diversas disposiciones.

Esta situación es bien distinta de otra con la que se la ha intentado equiparar. Parte de nuestra doctrina estima que, si el legislador puede disponer legítimamente la imposición simultánea de varias penas, esa posibilidad sirve como argumento para considerar también legítima la imposición conjunta de penas y sanciones administrativas, aunque para ello deban actuar distintos órganos competentes ${ }^{131}$. Sin embargo, una misma norma puede disponer la aplicación de varias penas en la medida en que esa variedad de penas no signifique una doble valoración, sino que la expresión "cuantitativa" del desvalor que se asigna a la única infracción cometida. La imposición de sanciones penales y administrativas, por el contrario, implica necesariamente la constatación de dos infracciones - la penal y la administrativaque, si se refieren a un mismo hecho y la sancionan con idéntico fundamento, implican una doble valoración, por lo que no son compatibles con el principio ne bis in idem en su vertiente sustantiva.

\subsection{Complementariedad con la vertiente procesal de ne bis in idem}

La conclusión anterior se ve especialmente reforzada cuando se considera el alcance de la faz procesal del ne bis in idem y su relación con la prohibición en sentido sustantivo. Aunque se acepte que ellos constituyen "dos estándares susceptibles de ser estrictamente diferenciados en atención a sus respectivas condiciones operativas" ${ }^{132}$, no cabe duda de que la vertiente sustantiva y procesal están profundamente conectadas y son, en buena medida,

${ }^{131}$ HERNÁNDEZ, “Actividad administrativa”, cit. nota n 45, pp. 571-572 pregunta “¿Por qué el legislador que puede disponer legítimamente la imposición simultánea de varias penas no puede prever la imposición conjunta de penas y sanciones administrativas sólo porque para ello deben actuar distintos órganos competentes? En términos absolutos no se aprecia ninguna justificación razonable". En sentido similar MAÑALICH, "El principio ne bis in idem", cit. nota $n^{\circ}$ 9, p. 559, considera que si la prohibición de punición múltiple no proscribe que un único tribunal (hipotéticamente) competente pueda imponer conjuntamente sanciones penales y administrativas, eso también ha de valer para el caso de que sean dos órganos diferentes los habilitados para imponer una y otra sanción por separado. Y el argumento que ofrece para estimar que el ne bis in idem en sentido sustantivo no prohíbe lo anterior, es que nuestro Código penal exhibe recurrentemente esta técnica legislativa - posibilidad de imposición conjunta de una pena privativa de libertad y de una pena pecuniaria- por lo que "sería a todas luces ocioso detenerse a demostrar que semejante objeción es simplemente absurda".

${ }^{132}$ MAÑALICH, "El principio ne bis in idem frente a la superposición”, cit. nota n 9, p. 547. 
complementarias $^{133}$. Su separación radical, en tanto, debilita el principio y puede terminar por diluirlo ${ }^{134}$.

La prohibición de doble juzgamiento se considera fundamentada en la garantía del debido proceso, pero su cometido específico es el de evitar un doble riesgo para el ciudadano o, como dicen otros, prohibir el hostigamiento procesal, poniendo el acento en que el órgano persecutor tiene una única oportunidad para hacer efectiva la pretensión punitiva estatal, con lo que se compensa la radical asimetría que existe entre este órgano y el imputado ${ }^{135}$. Pues bien, en uno u otro caso, el riesgo o el hostigamiento existen en razón del objetivo que se persigue: imponer una sanción. El procedimiento no tiene sentido por sí mismo, sino en función de la aplicación de la normativa sustantiva y según eso adopta sus especiales características. Que el proceso penal esté dirigido a la eventual condena del imputado es lo que lo transforma en un riesgo en sí mismo y constituye parte estructural de lo que puede ser considerado un hostigamiento procesal. Por eso, aun existiendo absolución -por lo que no existe riesgo de que se vulnere la vertiente sustantiva del principio-, el ne bis in idem procesal prohíbe iniciar un nuevo procedimiento sobre el mismo hecho.

Visto lo anterior, no tiene mayor sentido que el legislador estipule dos sanciones para un mismo ilícito, aunque sea con el objetivo de completar o enfatizar el desvalor que le asigna, que puedan ser impuestas en dos procesos distintos. La realización de un procedimiento sancionatorio implica la prohibición de iniciar un segundo procedimiento para imponer la otra sanción, por lo que solo una de ellas podría ser aplicada para no vulnerar la prohibición de doble juzgamiento ${ }^{136}$. Poco importaría que la suma de las dos sanciones todavía se entienda dentro de lo que es proporcionado como respuesta frente a la infracción cometida, de todos modos su imposición queda prohibida. En este sentido, Alcácer Guirao concluye que la prohibición de doble castigo queda subordinada a la, lógicamente previa, prohibición de doble enjuiciamiento ${ }^{137}$.

${ }^{133}$ Cfr. HORMAZÁBAL / BUSTOS, “Principio de legalidad”, cit. nota no 30, p. 168-169.

${ }^{134}$ Conclusión a la que arriba FALLET, ¿Es posible ..., cit. nota $\mathrm{n}^{\circ}$ 8, p. 70, luego de analizar la jurisprudencia de los Tribunales Constitucionales de España y Argentina, "la división del non bis in idem en dos la debilita y diluye, facilitando las posibilidades de su vulneración por parte de los organismos titulares del ius puniendi estatal [...] Tanto la jurisprudencia del TC como la doctrina partidaria de distinguir las dos vertientes se colocan, involuntariamente, en una actitud teórica proclive a aceptar dichas posibilidades de quebrantamiento de la garantía". A esto también alude el Tribunal Constitucional español en STC 177/1999, de 11 de octubre, en que afirma que la dimensión procedimental del bis in idem — la prevalencia del orden penal— "no puede ser interpretada en oposición a la material, en tanto que esta última atiende no al plano formal, y en definitiva instrumental, del orden de ejercicio o actuación de una u otra potestad punitiva, sino al sustantivo que impide que el sujeto afectado reciba una doble sanción por unos mismos hechos, cuando existe idéntico fundamento para el reproche penal y el administrativo". Cit. por ALCÁCER GUIRAO, Rafael, "El derecho a no ser sometido a doble procesamiento: discrepancias sobre el bis in idem en el Tribunal Europeo de Derechos Humanos y en el Tribunal Constitucional", Justicia Administrativa, No 61 (2013), p. 34.

${ }^{135}$ MAÑALICH, "El principio ne bis in idem frente a la superposición”, cit. nota nº 9, p. 552.

${ }^{136}$ Una ley que no puede aplicarse carece de racionalidad pragmática, cfr. DÍEZ RIPOLLÉS, José Luis, La racionalidad de las leyes penales, $2^{\mathrm{a}}$ ed., Madrid: Trotta, 2013, p. 95

${ }^{137}$ ALCÁCER GUIRAO, "El derecho a no ser...", cit. nota no 134, p. 42. 
Llegados a este punto, cobra especial importancia que la prohibición de doble juzgamiento tenga sustento constitucional, como vimos al comenzar nuestras consideraciones. Porque entonces se hace evidente que impone restricciones al legislador, impidiéndole atribuir varias sanciones a "lo mismo" que se puedan imponer a través de dos procedimientos independientes. Esto no significa que no puedan coexistir dos regímenes sancionatorios -el penal y el administrativo-, sino que su aplicación conjunta -simultánea o sucesiva-respecto de un mismo hecho y con el mismo fundamento, está prohibida ${ }^{138}$.

\subsection{Límite formal}

Todavía puede plantearse una duda respecto de la posibilidad de imponer dos sanciones en un único procedimiento, que no queda prohibida por la vertiente procesal del principio.

En torno a esta cuestión es necesario formular algunas distinciones previas, de conformidad con lo explicado previamente. Cuando el legislador estipula diversas sanciones para un ilícito, por ejemplo, porque el tipo penal mismo indica varias penas copulativas, porque se trata de penas accesorias a las principales, o porque se emplea alguna otra técnica de remisión, estamos frente a un único ilícito y una única valoración, que se expresa en esa penalidad compuesta. Todas esas sanciones se pueden imponer, algo que deberá ocurrir necesariamente en un único procedimiento. Esta situación no vulnera la prohibición de doble valoración.

En cambio, queda prohibida la opción de establecer una segunda pena asociada a una norma de sanción distinta y autónoma respecto de la primera, esto es, que configura "otro ilícito", pero que sanciona el mismo hecho y con idéntico fundamento, aun cuando pueda aplicarse, eventualmente, en un único procedimiento. El juez no podría imponer ambas sanciones interpretando que se trata de un mismo y único ilícito descrito a través de dos disposiciones distintas, de modo que la segunda solo implica un énfasis en la valoración del ilícito y la respuesta penal que le corresponde, porque el legislador habría utilizado un mecanismo que implica una doble valoración, por lo que resulta prohibido.

\footnotetext{
${ }^{138}$ Lo que planteamos puede verse como el reflejo inverso de lo que propone MAÑALICH, "El principio ne bis in idem frente a la superposición", cit. nota $\mathrm{n}^{\circ} 9$, p. 561, quien parte por "reparar en las implicaciones de la heterogeneidad de los regímenes sancionatorios [penal y administrativo] cuya potencial activación define el horizonte de las instancias de investigación o persecución concurrentes" y reconoce que "en la medida en que la potencial activación de ambos regímenes sancionatorios no pueda tener lugar a través de una misma instancia de investigación o persecución, es claro que la eventual proscripción de una doble investigación o persecución necesariamente llevaría a que alguno de ellos no llegase a activarse". Pero sobre la base de que "esto resultaría manifiestamente incongruente con la validación legislativa de la coexistencia de ambos regímenes" y de que "no pueda objetarse la legitimidad de la configuración dualista de los regímenes sancionatorios en concurrencia", entonces "no hay base para una objeción de principio en contra de la admisibilidad de la sustanciación de procesos (jurisdiccionales o administrativos) encaminados a la potencial imposición de sanciones en uno y otro frente". En otras palabras, considera que como el legislador ha dispuesto la existencia de dos regímenes diferentes y ello es legítimo, puede admitirse su sustanciación conjunta para la aplicación de dos infracciones que, en conjunto, permiten completar el juicio de desvalor sobre la conducta.
} 
Si partimos de la premisa de que el ne bis in idem en su vertiente sustantiva busca garantizar tanto la proporcionalidad de la respuesta penal como la seguridad jurídica, entonces prohíbe al legislador estipular varias penas a través de diversas disposiciones, cada una de las cuales configure un ilícito independiente que, por lo mismo, pueda ser objeto de procesos diferentes -sea dos procesos penales o uno penal y uno administrativo- pues eso genera la situación de riesgo e inseguridad que el ne bis in idem pretende evitar.

En suma, la proscripción del doble castigo adquiere relevancia y justifica su existencia -con independencia de la vertiente procesal del ne bis in idem - en los casos de imposición de dos sanciones por un mismo hecho y con idéntico fundamento en una misma causa, lo que puede entenderse como un concurso aparente de leyes penales ${ }^{139}$.

Antes decíamos que esta clase de concurso no resulta proscrito por el ne bis in idem en relación con su tipificación abstracta, sino únicamente en cuanto a la posibilidad de imponer las diversas penas concurrentes. Pero a ello habría que agregar que esa posibilidad de establecer normas que aludan a un mismo injusto, tiene sentido solo en la medida en que existan supuestos en que la norma que resulta desplazada al solucionar el concurso a los que sea aplicable, sin que concurra la otra ley penal. Si, por el contrario, las leyes son idénticas y la segunda solo pretende aumentar la severidad de la sanción, constituye una técnica de tipificación proscrita por el principio en estudio.

Haciendo un símil con el fundamento que se asigna a la vertiente procesal del ne bis in idem, en el sentido de que el órgano persecutor tiene una sola oportunidad para perseguir el ilícito, podemos decir que el legislador tiene que valorar la respuesta penal a través de una sola norma. Si cambias el juicio de desvalor y pretende sancionar más gravemente el ilícito, deberá hacerlo a través de la única norma de sanción (la que puede contemplar varias penas y estar estructurada a través de varias disposiciones).

\section{Sanciones penales y administrativas}

No podemos terminar sin hacer alusión a lo que las consideraciones expuestas implican para enjuiciar la posibilidad de imponer sanciones penales y administrativas por un mismo hecho.

\subsection{Requisito de identidad}

En relación con esta eventual concurrencia de sanciones, lo primero a dilucidar es si estamos realmente ante "lo mismo", esto es, si existe identidad de sujeto, hecho y fundamento. Sin entrar al detalle de lo que significa esta triple identidad, consideramos que ella es más bien excepcional, por las diferencias radicales que existen entre las infracciones penales y administrativas. Diferencias que obedecen a que se estructuran con una lógica distinta, que

${ }^{139}$ Cfr. ALCÁCER GUIRAO, “El derecho a no ser...”, cit. nota n 134, p. 42. 
responde a su diversa función; "mientras que la pena apunta a prevenir la lesión de bienes jurídicos, lo que la sanción administrativa procura es asegurar el adecuado funcionamiento de los sectores sociales sometidos a regulación" ${ }^{140}$. Por lo tanto, la regla general será que no pueda afirmarse la triple identidad y, en consecuencia, que las sanciones sean compatibles. Sin embargo, este es solo el punto de partida, pues la cuestión ha de resolverse por un análisis caso a caso ${ }^{141}$.

En nuestra jurisprudencia, cuando se admite la duplicidad de sanciones se hace sobre la base de la diversidad de fundamento para su imposición, muchas veces reflejada en el contenido mismo de la sanción impuesta. Por ejemplo, frente a un quebrantamiento de condena, se advierte que la sanción penal y la administrativa "no cumplen un mismo objeto", pues la segunda "busca restablecer el orden quebrantado y compeler al respeto interno, fundamentalmente en el caso, lo que apunta al respeto de las exigencias impuestas a quien goza de un beneficio; y el precepto del Código Penal, que castiga a quien ha quebrantado una sentencia judicial, esto es, una orden dispuesta por uno de los poderes del Estado, en el ejercicio soberano de las facultades que le son propias y en representación del mismo, para el castigo de un delito"142; o en el caso de los extranjeros que, condenados por un delito, luego son expulsados del país: "la disposición administrativa obedece a razones de bienestar común y de orden social, fines que son diversos a la sanción penal impuesta"143.

Sin embargo, otros casos en que también podrían haberse llegado a la misma decisión han sido objeto de la contraria. Así, por ejemplo, en diversas situaciones de responsabilidad de jueces -por razones bien distintas: falsear información relativa a una audiencia ${ }^{144}$, enviar el borrador de la sentencia que se iba a dictar a una de las partes ${ }^{145}$, omitir bienes en la declaración de patrimonio ${ }^{146}$, malos tratos ${ }^{147}$, etc. - se ha negado la posibilidad de imponer una pena porque ya se había sancionado en sede administrativa. Estas decisiones no resultan del todo satisfactorias, por una parte, porque ofrecen una diferencia de criterio poco justificada, máxime cuando en estos ejemplos se trataba siempre de sanciones disciplinarias, que generalmente se consideran compatibles con las penales por la diversidad de fundamentos a que obedecen (lo que se estaría sancionando administrativamente es la infracción deber de lealtad que existe cuando entre el sancionado y la Administración se da una especial relación de subordinación). Por otra

\footnotetext{
${ }^{140}$ GARCÍA CAVERO, Percy "El principio del ne bis in ídem material en caso de concurrencia de pena y sanción administrativa", Polít. Crim. Vol. 11, No 21, (2016), A2, pp. 21-33, p. 26.

${ }^{141}$ En el mismo sentido OTTAVIANO, La garantía, cit. nota $\mathrm{n}^{\circ}$ 4, p. 54 afirma que "no parece que sea razonable una toma de postura general y en abstracto ya sea a favor o en contra de la multiplicación de sanciones y procedimientos penales y administrativos". Similar DE LEÓN VILLALBA, Acumulación, cit. nota nº 7, p. 495. ${ }^{142}$ SCS Rol No 9747-201, considerando $7^{\circ}$.

${ }^{143}$ SCA Santiago Rol No 1381-2015, confirmada por SCS Rol No 13.004-2015. En el mismo sentido, SCS Rol $\mathrm{N}^{\mathrm{o}} 1.616-2013$.

144 SCA Temuco Rol No $1100-2011$.

${ }^{145}$ SCA Concepción Rol No 311-2014 y SCS Rol No 21.395-2014.

146 SCS Rol No 4116-2012.

${ }^{147}$ SCA Copiapó Rol N 39-2006, confirmada por SCS Rol Nº 1565-2006.
} 
parte, la solución es criticable también porque en la práctica ha significado hacer primar la sanción menos grave, la administrativa, por sobre la penal ${ }^{148}$.

Ahora bien, puede advertirse que las excepciones son cada vez más frecuentes en la medida en que estamos ante un proceso de paulatina administrativización del Derecho penal ${ }^{149}$. En algunos sectores, como el del Derecho penal económico, la intervención penal se estructura a través de delitos de peligro abstracto en torno a bienes jurídicos colectivos, difusos y construidos normativamente en función de la regulación administrativa del sector de que se trata, de tal modo que las diferencias con la regulación administrativa prácticamente desaparecen $^{150}$.

\subsection{Aplicabilidad de la prohibición al ámbito administrativo sancionador}

Las disposiciones que consagran la vertiente procesal del ne bis in idem se refieren inequívocamente, por lo general, solo al procedimiento penal, mientras que su extensión al administrativo es objeto de cierta controversia ${ }^{151}$. Sin embargo, la tendencia parece ser la de que la garantía debe abarcar también los casos de coincidencia penal y administrativa, cuando la reacción sancionatoria en este último ámbito sea esencialmente equivalente a la penal. Mención especial merece, a este respecto, la jurisprudencia del Tribunal Europeo de Derechos Humanos, que ha establecido que la calificación de una materia como "penal" no puede quedar liberada a lo que los Estados entiendan por tal, sino que es un concepto

\footnotetext{
${ }^{148}$ Es relevante consignar que en todos estos casos ambas sanciones resultan imponibles por un mismo órgano: la Corte de Apelaciones, actuando con sus facultades administrativo-disciplinarias o jurisdiccionales en cada caso. Además, en las resoluciones citadas se suele esgrimir un argumento interpretativo: al aplicar una medida disciplinaria al imputado se entiende, implícitamente, que la Corte habría entendido (al pronunciarse sobre la procedencia de esa medida) que el hecho imputado no importaba un delito penal, ya que conforme al inciso final del artículo 537 COT, las sanciones administrativas establecidas en el mismo se entienden respecto de faltas o abusos que las leyes no califiquen de crimen o simple delito.

149 Sobre este proceso, clásico, SILVA SÁNCHEZ, Jesús María, La expansión del Derecho penal, $2^{\mathrm{a}}$ ed., Civitas, Madrid, 2001, p. 121 y ss. Sobre el fenómeno en el caso de la punibilidad del uso de información privilegiada, GARCÍA PALOMINOS, Gonzalo. "La idealización y la administrativización de la punibilidad del uso de Información Privilegiada. Un análisis de los discursos penales en la doctrina chilena", Polít. Crim. Vol. 10, $\mathrm{N}^{\circ} 19$ (2015), A5, pp. 119-158, passim.

${ }^{150}$ Así, por ejemplo, al comparar el delito de conducción bajo los efectos de bebidas alcohólicas del art. $379 \mathrm{CP}$ frente a la correspondiente infracción administrativa, el TC español en sentencia 2/2003, destaca que existe una diferencia, porque la infracción penal requiere acreditar que en el caso concreto la ingestión haya tenido influencia en la capacidad psico-física del conductor, mientras que la administrativa opera en forma automática. Sin embargo, consideró que por compartir ambas un elemento nuclear común -conducir un vehículo de motor habiendo ingerido alcohol por sobre las tasas determinadas - existía la identidad exigida para que opere la prohibición de bis in idem (FJ. $5^{\circ}$ ). En el fondo, en ese elemento común -y en la inexistencia de otros elementos diferenciadores - se advierte que la conducta prohibida y el objetivo que se persigue con la norma sancionadora son fundamentalmente idénticas, en la línea de la función administrativa, pues se trata de una conducta muy alejada de la lesión individual de un bien jurídico concreto.

${ }^{151}$ Un análisis particular de diversos instrumentos internacionales, en su texto y aplicación, en OTTAVIANO, La garantía, cit. nota ${ }^{\circ}$ 4, pp. 167-171, pp. 212-219, pp. 248-254 y pp. 299-300. En relación con la Convención Americana de Derechos Humanos, el autor advierte que pese al tenor literal restrictivo con que es consagrada la garantía, su aplicación se ha ampliado a casos no penales (pp. 158-171).
} 
autónomo con una significación propia en el orden internacional, que se construye según los siguientes criterios (conocidos como criterios Engel ${ }^{152}$ ): la calificación jurídica de la infracción en el Derecho interno, la naturaleza del ilícito ${ }^{153}$ y la severidad de la sanción. De este modo, en el ámbito europeo se ha extendido la garantía del ne bis in idem a sanciones que son calificadas como meramente administrativas por la legislación nacional, pero que tendrían "una naturaleza sustancialmente penal"154.

Coincidimos con Alcacer Guirao cuando concluye que "la generosa equiparación por parte de Estrasburgo entre sanciones (y procesos) administrativo-sancionadores y penales a la hora de fijar el alcance del artículo 4 P7, si bien no impone una determinada configuración del sistema punitivo de los Estados, sí abona la idea de una unidad de soberanía sancionadora, al menos por cuanto, a los efectos del bis in idem"155.

La aplicación de este criterio por el TEDH ha llevado incluso a plantear la necesidad de renunciar al sistema de doble punibilidad, administrativa y penal, que se plantea cada vez que existen delitos que tienen un área aplicativa que se superpone con aquella cubierta por el ilícito administrativo paralelo, aun cuando esta superposición haya sido establecida conscientemente por el legislador ${ }^{156}$.

\subsection{Consecuencias en la interpretación}

Como decíamos, existen ámbitos en los que la intervención penal se administrativiza y coincide, fundamentalmente, con la administrativa. Un ejemplo es el de la regulación del Mercado de Valores y la sanción por uso de información privilegiada. Tanto la doctrina como la jurisprudencia consideran que el objeto de protección es el mismo en sede administrativa y penal, pues en ambos sectores se hace referencia a la transparencia del mercado o al mecanismo de la libre formación de precios para garantizar la transparencia e igualdad de oportunidades entre los inversores ${ }^{157}$. El problema que se presenta en este caso es que, a pesar de la asimilación fundamental entre ambos sistemas, la propia Ley № 18.045, de Mercado

152 STEDH de 8 de junio de 1976 (caso Engel y otros contra Países Bajos).

${ }^{153}$ Es considerado el criterio más importante. Para determinar cuál es la naturaleza de la infracción, el Tribunal tiene en cuenta el sector de la población a que va dirigida la norma transgredida, el tipo y naturaleza de los intereses protegidos y la existencia de un objetivo disuasorio y represivo. Sobre estos criterios, vid. CARPIO BRIZ, "Europeización", cit. nota n 108, pp.229-231.

${ }^{154}$ Cfr. VIGANO, Francesco, "Ne bis in idem e contrasto agli abusi di mercato: una sfida per il legislatore e i giudici italiani. Riflessioni de lege lata e ferenda sull'impatto della sentenza Grande Stevens nell'ordinamento italiano", en Diritto penale contemporaneo, $\mathrm{N}^{\circ} 1$ (2016), p. 189, a propósito del caso Grande Stevens contra Italia, la STEDH de 4 de marzo de 2014, sanciona a Italia por infringir el ne bis in idem al imponer dos sanciones, una administrativa y otra penal, por un mismo comportamiento (conductas abusivas en el mercado financiero). Estos criterios fueron también tenidos en consideración en el caso Kurdov e Ivanov contra Bulgaria, STEDH 31 de mayo de 2011, para concluir que la multa impuesta en sede administrativa, por haber vulnerado las normas de seguridad contra incendios, no tenía carácter penal (considerando también que su cuantía no era muy elevada).

155 ALCÁCER GUIRAO, “El derecho a no ser...”, cit. nota n 134, p. 44.

${ }^{156}$ Cfr. VIGANO, "Ne bis in idem", cit. nota ${ }^{\circ} 154$, pp. 186-202) p. 197.

${ }^{157}$ Por todos GARCÍA PALOMINOS, “La idealización”, cit. nota n 149, p. 148. 
Polit. crim. Vol. 13, № 26 (Diciembre 2018) Art. 8, pp. 952-1002.

[http://www.politicacriminal.cl/Vol_13/n_26/Vol13N26A8.pdf]

de Valores, habría establecido un régimen de acumulación de sanciones penales y sanciones administrativas, de conformidad con lo previsto por el art. 58 en relación con los ilícitos tipificados en los arts. 59 y 60 de esa misma ley ${ }^{158}$.

De conformidad con lo hasta aquí expuesto, aplicar conjuntamente las dos sanciones es inconstitucional por infringir la prohibición de ne bis in idem ${ }^{159}$, tanto en su vertiente sustantiva como en la procesal, pues inevitablemente sería necesario imponerlas a través de procedimientos separados.

Lo que corresponde hacer en un caso como éste, entonces, es procurar interpretar esa disposición de un modo que sea conforme con la Constitución. La posibilidad que la ley consigna de acumular la responsabilidad habrá que estimarla como un indicio de que el legislador persigue fines diversos con la imposición de cada una de las sanciones concurrentes y que para el logro de esos fines es necesario imponer consecuencias distintas. En otras palabras, hay que partir de la base de que si no ha sido posible ofrecer una respuesta única suficiente para abarcar todo el des valor de la conducta realizada, en sede administrativa o penal, se debe a que estos sistemas apuntan a finalidades diversas y por ello operan también de un modo diverso, siendo necesario recurrir a ambos. Entonces podría concluirse que falta la identidad de fundamento, necesaria para alegar una vulneración al ne bis in idem, en la medida en que "como consecuencia de un único hecho realizado por un mismo sujeto, el Estado se ve obligado a responder mediante procesos y sanciones separados para realizar fines legítimos, en tanto para la adecuada consecución de esos fines resulte indispensable una respuesta sancionadora distinta"160.

Ahora bien, la conclusión anterior no pretende quedarse únicamente en una declaración formal -pues entonces no sería más que un fraude de etiquetas-, sino que debe materializarse en la forma de interpretación de cada una de las infracciones, de sus requisitos y condiciones de legitimidad, muy especialmente al valorar la proporcionalidad de la reacción punitiva. Si no es posible identificar una real diferencia entre la sanción penal y la administrativa que justifique su persecución e imposición a un mismo hecho, solo una de ellas será imponible, pues podría decirse - al modo como hace el Tribunal Europeo de Derechos Humanos- que

\footnotetext{
${ }^{158}$ Disposiciones similares se encuentran en el artículo 44 de la Ley No 18.046 sobre Sociedades Anónimas; el artículo 61 de la LOC del Banco Central, etc. Otros ejemplos, también en el ámbito de las sanciones disciplinarias en ORTIZ / ARÉVALO, Las consecuencias, cit. nota n ${ }^{\circ}$ 107, p. 105.

${ }^{159}$ En Argentina, parte de la doctrina postula que debería declararse la inconstitucionalidad de disposiciones como el art. 17 del Código Tributario argentino, que dispone: "Las penas establecidas por esta ley serán impuestas sin perjuicio de las sanciones administrativas fiscales”, cfr. FALLET, ¿Es posible ..., cit. nota $\mathrm{n}^{\circ} 8$, p. 124 , con referencias.

${ }^{160}$ OTTAVIANO, La garantía, cit. nota $\mathrm{n}^{\circ}$ 4, p. 50 (el destacado es nuestro). Aplica lo anterior tanto para la vertiente sustantiva como para la procesal del principio ne bis in idem, en tanto "la multiplicación de procesos resulte necesaria para la consecución de fines legítimos e inocua porque la realización de todos ellos no implica un trato incompatible con el respeto de la dignidad del imputado".
} 
pese a ser formalmente administrativa, esa sanción tiene "una naturaleza sustancialmente penal"161.

\section{Consideraciones finales}

Sin cuestionar que el legislador goza de un amplio margen de libertad para decidir lo que se sanciona y en qué medida, pues es quien goza de la legitimidad democrática para adoptar las decisiones político-criminales de una sociedad, debe hacerlo siempre en el marco de lo que establece la Constitución ${ }^{162}$ y los tratados internacionales de derechos humanos ${ }^{163}$.

Desde la reflexión jurídico-penal es necesario apoyar la labor del legislador, para que sea más racional y reconozca sus límites, para lo cual sería necesario profundizar en la elaboración de una teoría y una técnica de la legislación penales que sienten los presupuestos materiales y formales de la decisión legislativa penal, uno de los cuales es el principio del ne bis in idem. Una tarea poco atendida hasta ahora pues, como destaca Díez Ripollés, el positivismo jurídico ha impuesto ataduras a la reflexión jurídicopenal que le han impedido desarrollar todas sus potencialidades racionalizadoras. "La reflexión jurídico penal se ha visto atrapada en una estrategia equivocada: no hay que asumir el arbitrio irracional del legislador e intentar atemperarlo mediante principios limitadores en el momento de la aplicación del derecho, sino que hay que someter al legislador desde el inicio de su actividad a criterios racionales de legislación, previendo los medios jurídicopolíticos para ello"164.

En no pocos casos los problemas asociados a una eventual infracción del principio ne bis in idem vienen determinados por una equivocada técnica legislativa más que por una decisión

\footnotetext{
${ }^{161}$ Para evitar controversias interpretativas, sería conveniente que las disposiciones que permiten esa duplicidad de sanciones contuvieran una mención explícita a la posibilidad de aplicación conjunta cuando a través la infracción penal y la administrativa se "afectan diversos intereses" o si, en el caso concreto, cada sanción "tiene diverso fundamento". Un ejemplo de esta técnica legislativa lo ofrece el artículo 44 inciso 2 de la Ley española 34/2002, de Telecomunicaciones, que dice: "La imposición de una sanción prevista en esta Ley no impedirá la tramitación y resolución de otro procedimiento sancionador (...) cuando la conducta infractora se hubiera cometido utilizando técnicas y medios telemáticos o electrónicos y resulte tipificada en otra Ley, siempre que no haya identidad del bien jurídico protegido" (el destacado es nuestro). Pero en dicho país también se encuentran también ejemplos de un error inverso, pues existen disposiciones que estipulan que la imposición de una pena excluirá, en todo caso, la de la sanción administrativa; el problema es que no se exige que concurra la triple identidad, por lo que no responden al principio ne bis in idem. Cfr. y ejemplos en ALARCÓN, La garantía "non bis in idem", cit. nota $\mathrm{n}^{\circ} 49$, p. 81 y 82.

162 " $[\mathrm{N}]$ o se discute la procedencia del amplio margen de apreciación o flexibilidad que goza el legislador al momento de configurar un sistema sancionatorio, pero esto no lo inmuniza frente a un control de constitucionalidad de la ley (...) un ajuste en la reacción punitiva del Estado no puede, desde el punto de vista constitucional, diseñarse de cualquier forma”, STC 2896, 25 de agosto de 2016, voto de prevención, considerando $6^{\circ}$. En España, lo plantea en términos similares NIETO GARCÍA, Alejandro, "El principio non bis in ídem", Revista Vasca de Administración Pública, № 28 (1990), pp. 161-162.

${ }^{163}$ Cfr. VIGANO, "Ne bis in idem", cit. nota $\mathrm{n}^{\circ} 154$, p. 187.

${ }^{164}$ DÍEZ RIPOLLÉS, La racionalidad, p. 103, cit. nota $n^{\circ} 136$.
} 
Polit. crim. Vol. 13, № 26 (Diciembre 2018) Art. 8, pp. 952-1002.

[http://www.politicacriminal.cl/Vol_13/n_26/Vol13N26A8.pdf]

consciente del legislador ${ }^{165}$. Pero, cualquiera sea el caso, el legislador es el responsable de establecer un sistema que permita aplicar efectivamente sus criterios valorativos y políticocriminales, con respeto por la dignidad y garantías que se reconocen a los ciudadanos. En este sentido, concordamos con Carpio Briz cuando concluye que "si el Estado no quiere dejar escapar la completa desvaloración punitiva de determinados hechos por una mala actuación de su aparato sancionatorio está obligado a promulgar una regulación material y procesal de los ilícitos que ponga dicho interés en su ámbito de esfuerzo y responsabilidad y no en el sacrificio de los derechos" $" 166$.

Entonces, el legislador habría de asumir que está constreñido por ciertos aspectos formales o técnicos a la hora de diseñar e implementar sus decisiones, entre los que se cuenta el principio ne bis in idem. No se pretende con ello dar prioridad al aspecto técnico por sobre la decisión política, pues es evidente que las consideraciones técnico-jurídicas están subordinadas a las sustantivas ${ }^{167}$, pero hay que destacar que existen exigencias formales que se alzan como límite en un sistema que procura respetar sus propios fundamentos.

\footnotetext{
${ }^{165}$ En efecto, se evita el riesgo de una doble valoración sobre lo mismo, cuando las formulaciones de los tipos penales son excluyentes entre sí, cuando se utiliza cláusulas de reenvío entre los ilícitos eventualmente concurrentes, cuando se establece un sistema explícito de compensación de sanciones, etc.

166 CARPIO BRIZ, “Europeización”, cit. nota no 108, p. 240.

167 Cfr. MARTÍN REBOLLO, Luis, "La técnica legislativa: reflexiones discretas sobre el método y el procedimiento", en: CORONA FERRERO, Jesús; PAU VALL, Francesc; TUDELA ARANDA, José (coords.), La técnica legislativa a debate, Madrid: 1994, pp. 73-82, p. 75 y ORTIZ DE URBINA GIMENO, Iñigo, Teoría de la legislación y Derecho penal, manuscrito inédito, Madrid, 2002, p. 14, n. 45.
} 
OSSANDÓN, Magdalena. "El legislador y el principio ne bis in idem".

\section{Bibliografía}

ALARCÓN SOTOMAYOR, Lucía, La garantía "non bis in idem" y el procedimiento administrativo sancionador, Madrid: Iustel, 2008.

ALCÁCER GUIRAO, Rafael, "El derecho a no ser sometido a doble procesamiento: discrepancias sobre el bis in idem en el Tribunal Europeo de Derechos Humanos y en el Tribunal Constitucional", Justicia Administrativa, No 61 (2013), pp. 25-52.

ALCHOURRÓN, Carlos; BULYGIN, Eugenio, "Norma jurídica", en: GARZÓN VALDÉS, Ernesto; LAPORTA, Francisco (eds.), El derecho y la justicia, Madrid: Trotta, 1996, pp. 133-147.

ARROYO ZAPATERO, Luis, "Principio de legalidad y reserva de ley en materia penal", Revista Española de Derecho Constitucional, N 8 (1983), pp. 9-46.

BOLDOVA PASAMAR, Miguel Ángel, "Los principios del Derecho penal”, en: ROMEO CASABONA, Carlos María; SOLA RECHE, Esteban y BOLDOVA PASAMAR, Miguel Ángel (coords.), Derecho penal. Parte general, Granada: Comares, 2013, pp. 33-49.

BULLEMORE, Vivian; MACKINNON, John, Curso de Derecho Penal, Tomo II, Santiago: LexisNexis, 2005.

BULLEMORE, Vivian; MACKINNON, John, Curso de Derecho penal, $2^{\mathrm{a}}$ ed., Tomo III, Santiago: Legal Publishing, 2009.

BUSTOS RAMÍREZ, Juan; HORMAZÁBAL MALARÉE, Hernán, Lecciones de Derecho penal. Parte General, Madrid: Trotta, 2006.

CANO CAMPOS, Tomás, "Non bis in idem, prevalencia de la vía penal y teoría de los concursos en el derecho administrativo sancionador", Revista de Administración Pública, $\mathrm{N}^{\circ} 156$ (2001), pp. 191-249.

CANO MATA, Antonio, "Potestad normativa sancionadora de las Comunidades Autónomas", Revista de Administración Pública, No 119 (1989), pp. 199-232.

CARPIO BRIZ, David, "Europeización y reconstitución del non bis in idem”, en: MIR PUIG, Santiago; CORCOY BIDASOLO, Mirentxu (dirs.), Constitución y sistema penal, Madrid: Marcial Pons, 1989, pp. 223-242.

CONTRERAS GUERRERO, Pablo, "Una tesis para entender la medida de la pena en los casos de reiteración de delitos de la misma especie: análisis de las reglas penológicas contenidas en el artículo 351 del Código Procesal Penal a la luz del Principio de Proporcionalidad Constitucional”, Polít. Crim., Vol. 9, No 18 (2014), A10, pp. 614667, en: http://www.politicacriminal.cl/Vol_09/n_18/Vol9N18A10.pdf [visitado el 14.08.2017].

CORDERO QUINZACARA, Eduardo, Derecho administrativo sancionador, Santiago: Legal Publishing-Thomson Reuters, 2014. 
Polit. crim. Vol. 13, № 26 (Diciembre 2018) Art. 8, pp. 952-1002.

[http://www.politicacriminal.cl/Vol_13/n_26/Vol13N26A8.pdf]

COUSIÑO MACIVER, Luis, Derecho penal chileno. Parte general, Tomo I, Santiago: Ed. Jurídica de Chile, 1975.

COUSO SALAS, Jaime, "Comentario previo a los Arts. 74 y 75. El régimen concursal en el derecho chileno. Tratamiento doctrinario y jurisprudencial”, en: COUSO SALAS, Jaime; HERNÁNDEZ BASUALTO, Héctor (dir.), Código penal comentado. Parte General. Doctrina y jurisprudencia, Santiago: Abeledo Perrot - Legal Publishing, 2011, pp. 234-239.

CUBERO MARCOS, José Ignacio, El principio non bis in idem en la Ley vasca de la potestad sancionadora, Oñati, Instituto Vasco de Administración Pública, 2010.

CUERDA RIEZU, Antonio, "El concurso de delitos en el Borrador de anteproyecto de Código Penal de 1990", Anuario de Derecho Penal y Ciencias Penales, Tomo 44, ${ }^{\circ}$ 3 (1991), pp. 821-866.

CURY URZÚA, Enrique, Derecho Penal. Parte General, $8^{\mathrm{a}}$ ed., Santiago: Ediciones Universidad Católica de Chile, 2005.

DE LEÓN VILLALBA, Francisco Javier, Acumulación de sanciones penales y administrativas: sentido y alcance del principio "ne bis in idem", Barcelona: Bosch, 1998.

DE LEÓN VILLALBA, Francisco Javier, "Sobre el sentido del axioma ne bis in idem", en: ARROYO ZAPATERO, Luis y NIETO MARTÍN, Adán (coords.), El principio de ne bis in idem en el derecho penal europeo e internacional, Cuenca, Ediciones de la Universidad Castilla-La Mancha, 2007, pp. 17-36.

DÍAZ Y GARCÍA CONLLEDO, Miguel, "Ne bis in idem material y procesal", Revista de Derecho, Universidad Centroamericana, No 9 (2004), pp. 9-27.

DÍEZ RIPOLLÉS, José Luis, La racionalidad de las leyes penales, $2^{\mathrm{a}}$ ed., Madrid: Trotta, 2013.

ETCHEBERRY, Alfredo, Derecho penal. Parte general, Tomos II y III, $3^{\text {a }}$ ed., Santiago: Ed. Jurídica de Chile, 1998.

FALLET LA ROCCA, Lucas, ¿Es posible pensar el non bis in idem como una garantía unitaria? Estudio de los sistemas español y argentino, con referencia a la jurisprudencia de tribunales internacionales, Buenos Aires: Fabián J. Di Plácido Editor, 2015.

FERNÁNDEZ CRUZ, José Ángel, "Tribunal constitucional y derecho penal: un estudio crítico", Estudios Constitucionales, Año 12, No 2 (2014), pp. 187-238, en: http://www.scielo.cl/pdf/estconst/v12n2/art07.pdf [visitado el 10.02.2017].

FIANDACA, Giovanni; MUSCO, Enzo, Derecho Penal. Parte general, Trad. FERNANDO NIÑO, Luis, Bogotá (Colombia), Ed. Temis, 2006.

GARCÍA ALBERO, Ramón, Non bis in idem material y concurso de leyes penales, Barcelona: Cedecs, 1995.

GARCÍA CAVERO, Percy "El principio del ne bis in ídem material en caso de concurrencia de pena y sanción administrativa", Polit. Crim. Vol. 11, No 21 (2016), A2, pp. 21-33, en: http://www.politicacriminal.cl/Vol_11/n_21/Vol11N21A2.pdf [visitado el 07.02.2017].

GARCÍA DE ENTERRÍA, Eduardo, La Constitución como norma y el Tribunal Constitucional, Madrid: Civitas, 1985.

GARCÍA PALOMINOS, Gonzalo, "La idealización y la administrativización de la punibilidad del uso de Información Privilegiada. Un análisis de los discursos penales 
OSSANDÓN, Magdalena. "El legislador y el principio ne bis in idem".

en la doctrina chilena", Polít. Crim. Vol. 10, N¹9 (2015), A5, pp. 119-158, en: http://www.politicacriminal.cl/Vol_10/n_19/Vol10N19A5.pdf [visitado el 03.03.2017].

GARCÍA PINO, Gonzalo - CONTRERAS VÁSQUEZ, Gonzalo, "El derecho a la tutela judicial y al debido proceso en la jurisprudencia del Tribunal Constitucional chileno", Estudios Constitucionales, Año 11, No 2 (2013), pp. 229-282, en: http://www.scielo.cl/pdf/estconst/v11n2/art07.pdf [visitado el 06.11.2016].

GARRIDO MONTT, Mario, El homicidio y sus figuras penales, $2^{\mathrm{a}}$ ed., Santiago: Ed. Jurídica Conosur, 1994.

GARRIDO MONTT, Mario, Derecho penal. Parte Especial, Tomo III, $3^{\mathrm{a}}$ ed., Santiago: Ed. Jurídica de Chile, 2007.

GARRIDO MONTT, Mario, Derecho penal. Parte general, Tomo I, $2^{\mathrm{a}}$ ed., reimpresión, Santiago: Ed. Jurídica de Chile, 2009.

GARRIDO MONTT, Mario, Derecho penal. Parte general, Tomo II, $4^{\mathrm{a}}$ ed., reimpresión, Santiago: Ed. Jurídica de Chile, 2009.

GÓRRIZ ROYO, Elena, "Sentido y alcance del ne bis in idem respecto a la preferencia de la jurisdicción penal, en la jurisprudencia constitucional (En especial la STC 2/2003, 16 de enero)", Estudios penales y criminológicos, $\mathrm{N}^{\circ} 24$ (2003), pp. 187-271.

HASSEMER, Winfred, "El principio de proporcionalidad como límite de las intervenciones jurídico-penales", Trad. CASTIÑEIRA PALOU, M. Teresa; ROBLES PLANAS, Ricardo, en: VON HIRSCH, Andrew - SEELMAN, Kurt - WOHLERS, Wolfgang (ed. alemana); ROBLES PLANAS, Ricardo (ed. española) Límites al Derecho penal. Principios operativos en la fundamentación del castigo, Barcelona: Atelier, 201, pp. 193-200.

HENDERSON, Humberto, "Los tratados internacionales de derechos humanos en el orden interno: la importancia del principio pro homine", Revista del Instituto Interamericano de Derechos Humanos, vol. 39 (2004), pp. 71-99, en: http://www.corteidh.or.cr/tablas/R06729-3.pdf [visitado el 12.08.2016].

HERNÁNDEZ BASUALTO, Héctor, “Actividad administrativa, procedimiento sancionatorio-administrativo y proceso penal: algunas necesidades de coordinación legal", en: ARANCIBIA MATTAR, Jaime; ALARCÓN JAÑA, Pablo (coords.), Sanciones Administrativas. X Jornadas de Derecho Administrativo, Asociación de Derecho Administrativo, Santiago: Thomson Reuters, 2014, pp. 567-586.

HORMAZÁBAL MALARÉE, Hernán; BUSTOS RAMÍREZ, Juan José "Principio de legalidad y ne bis in idem", en: CARBONELL MATEU, Juan Carlos (coord.), Estudios penales en Homenaje al Profesor Cobo del Rosal, Madrid: Dykinson, 2005, pp. 163-170.

HUERTA TOCILDO, Susana, "El derecho fundamental a la legalidad penal", Revista española de Derecho Constitucional, Año 13, № 39 (1993), pp. 81-113.

ITURRALDE SESMA, Victoria, "Elementos semántico-sintácticos de indeterminación de los enunciados normativos en el lenguaje legal”, Theoria, $2^{\mathbf{a}}$ época, año III, $\mathrm{n}^{\mathbf{o}}$ 7-8 (1988), pp. 157-190.

ITURRALDE SESMA, Victoria, Lenguaje legal y sistema jurídico, Madrid: Tecnos, 1989.

JAKOBS, Günther, Derecho penal. Parte General. Fundamentos y teoría de la imputación, $2^{\mathrm{a}}$ ed., Trad. CUELLO CONTRERAS; SERRANO GONZÁLEZ DE MURILLO, Madrid: Marcial Pons, 1997. 
Polit. crim. Vol. 13, № 26 (Diciembre 2018) Art. 8, pp. 952-1002.

[http://www.politicacriminal.cl/Vol_13/n_26/Vol13N26A8.pdf]

LABATUT GLENA, Gustavo, Derecho penal, Tomo I, 9a ed. actualizada por Zenteno Vargas, reimpresión, Santiago: Ed. Jurídica de Chile, 2007.

LÓPEZ BARJA DE QUIROGA, Jacobo, El principio: non bis in idem, Madrid: Dykinson, 2004.

MADRID CONESA, Fulgencio, La legalidad del delito, Valencia: Universidad de Valencia, 1983.

MAÑALICH RAFFO, Juan Pablo, "El concurso de delitos: bases para su reconstrucción en el Derecho penal de Puerto Rico", Revista Jurídica de la Universidad de Puerto Rico, $\mathrm{N}^{\mathrm{o}} 74$ (2005), pp. 1021-1211.

MAÑALICH RAFFO, Juan Pablo, "El principio ne bis in idem en el Derecho penal chileno", Revista de Estudios de la Justicia, $\mathrm{N}^{\circ} 15$ (2011), pp. 139-169, en: http://web.derecho.uchile.cl/cej/doc/MA\%C3\%91ALICH\%20_10.pdf [visitado el 05.11.2015].

MAÑALICH RAFFO, Juan Pablo, "El principio ne bis in idem frente a la superposición del derecho penal y el derecho administrativo sancionatorio", Polít. Crim., vol. 9, $\mathrm{N}^{\circ} 18$ (2014), A8 pp. 543-563, en: http://www.politicacriminal.cl/Vol 09/n 18/Vol9N18A8.pdf [visitado el 03.12.2017].

MAÑALICH RAFFO, Juan Pablo, "La reiteración de hechos punibles como concurso real. Sobre la conmensurabilidad típica de los hechos concurrentes como criterio de determinación de la pena", Polít. Crim, Vol. 10, No 20 (2015) A3, pp. 498-527, en: http://www.politicacriminal.cl/Vol_10/n_20/Vol10N20A3.pdf [visitado el 14.08.2017].

MARTÍN REBOLLO, Luis, "La técnica legislativa: reflexiones discretas sobre el método y el procedimiento", en: CORONA FERRERO, Jesús; PAU VALL, Francesc; TUDELA ARANDA, José (coords.), La técnica legislativa a debate, Madrid: 1994, pp. 73-82.

MATUS ACUÑA, Jean Pierre, "La teoría del concurso (aparente) de leyes en la dogmática alemana, desde sus orígenes hasta el presente (primera parte)", Ius et praxis, vol. 6 , $\mathrm{N}^{\circ} 2$ (2000), pp. 295-371.

MIR PUIG, Santiago, Derecho penal. Parte general, $7^{\mathrm{a}}$ ed., $2^{\mathrm{a}}$ reimpr., Montevideo-Buenos Aires: BdeF, 2005.

MUÑOZ CLARES, José, Ne bis in idem y derecho penal. Definición, patología y contrarios, Murcia, Ed. Diego Marín, 2006.

MUÑOZ LORENTE, José, La nueva configuración del principio non bis in idem (Las sanciones administrativas como límite a la intervención de la jurisdicción penal. Especial referencia al ámbito ambiental), Madrid: Ed. La Ley, 2001.

NEUMANN, Ulfrid, "El principio de proporcionalidad como principio limitador de la pena", Trad. SÁNCHEZ-OSTIZ, Pablo, en: VON HIRSCH, Andrew - SEELMAN, Kurt WOHLERS, Wolfgang (ed. alemana); ROBLES PLANAS, Ricardo (ed. española) Límites al Derecho penal. Principios operativos en la fundamentación del castigo, Barcelona: Atelier, 2012, pp. 201-212.

NIETO GARCÍA, Alejandro, "El principio non bis in ídem", Revista Vasca de Administración Pública, No 28 (1990), pp. 157-172. 
OSSANDÓN, Magdalena. "El legislador y el principio ne bis in idem".

NIETO GARCÍA, Alejandro, Derecho Administrativo Sancionador, $4^{\mathrm{a}}$ ed., reimpresión, Madrid: Tecnos, 2006.

NIETO MARTÍN, Adán, El principio de ne bis in idem en el Derecho penal europeo e internacional, en: ARROYO ZAPATERO, Luis; NIETO MARTÍN, Adán (coord.), El principio de ne bis in idem en el Derecho penal europeo e internacional, Cuenca, Ediciones de la Universidad Castilla-La Mancha, 2007, pp. 9-16.

NOVOA MONREAL, Eduardo, Curso de Derecho penal chileno. Parte general, $3^{\mathrm{a}}$ ed., Santiago: Ed. Jurídica de Chile, 2005.

OLIVER CALDERÓN, Guillermo, "La exasperación de la pena en el concurso material de delitos: la reiteración de delitos de la misma especie", Revista de Derecho (Valdivia), vol. XXVI, $\mathrm{N}^{\mathrm{o}} 2$ (2013), pp. 167-188, en: http://www.scielo.cl/pdf/revider/v26n2/art07.pdf [visitado el 12.08.2017].

OSSANDÓN WIDOW, María Magdalena, La formulación de tipos penales. Valoración crítica de los instrumentos de técnica legislativa, Santiago: Ed. Jurídica de Chile, 2009.

ORTIZ DE URBINA GIMENO, Iñigo, Teoría de la legislación y Derecho penal, manuscrito inédito, Madrid, 2002.

ORTIZ QUIROGA, Luis; ARÉVALO CUNICH, Javier, Las consecuencias jurídicas del delito, Santiago: Ed. Jurídica de Chile, 2013.

OTTAVIANO, Santiago, La garantía del ne bis in idem. La prohibición de doble sanción y de doble enjuiciamiento penal y su tutela en los tratados internacionales de Derechos Humanos, México: Porrúa, 2013.

PASTOR, Daniel Roberto, Tendencias hacia una aplicación más imparcial del Derecho penal, Buenos Aires: Hammurabi, 2012.

PÉREZ LUÑO, Antonio-Enrique, La seguridad jurídica, Barcelona: Ariel, 1991.

PÉREZ MANZANO, Mercedes, La prohibición constitucional de incurrir en bis in idem, Valencia: Tirant lo Blanch, 2002.

PEÑARANDA RAMOS, Enrique, Concurso de leyes, error y participación en el delito, Madrid: Civitas, 1991.

PIÑA ROCHEFORT, Juan Ignacio, Derecho penal. Fundamentos de la responsabilidad, Santiago: Abeledo Perrot- LegalPublishing, 2010.

POLITOFF, Sergio; GRISOLÍA, Francisco; BUSTOS, Juan, Derecho Penal Chileno. Parte Especial, $2^{\text {a }}$ ed., Santiago: Ed. Jurídica Congreso, 2006.

POLITOFF, Sergio; MATUS, Jean Pierre; RAMÍREZ, María Cecilia, Lecciones de Derecho Penal chileno. Parte General, 2a ed., Santiago: Ed. Jurídica de Chile, 2004.

POLITOFF, Sergio; MATUS, Jean Pierre; RAMÍREZ, María Cecilia, Lecciones de Derecho Penal chileno. Parte Especial, $2^{\text {a }}$ ed., Santiago: Ed. Jurídica de Chile, 2005.

PRAMBS, Claudio, “Es posible sancionar las lesiones y el homicidio en concurso ideal?”, Revista de Derecho de la Pontificia Universidad Católica de Valparaíso, XXXIV (2010), pp. 459-474.

RAMÍREZ GÓMEZ, Salvador, El principio ne bis in idem en el ámbito tributario (Aspectos sustantivos y procedimentales), Madrid-Barcelona: Marcial Pons, 2001.

ROXIN, Claus, Teoría del tipo penal. Tipos abiertos y elementos del deber jurídico, Trad. BACIGALUPO ZAPATER, Buenos Aires: Depalma, 1979.

SAINZ MORENO, Fernando, "Seguridad Jurídica", en: MONTOYA MELGAR (dir.), Enciclopedia jurídica básica, tomo IV, Madrid: 1995, pp. 6108-6118. 
Polit. crim. Vol. 13, № 26 (Diciembre 2018) Art. 8, pp. 952-1002.

[http://www.politicacriminal.cl/Vol_13/n_26/Vol13N26A8.pdf]

SÁNCHEZ-OSTIZ GUTIÉRREZ, Pablo, Fundamentos de Política criminal. Un retorno a los principios, Madrid: Marcial Pons, 2012.

SILVA SÁNCHEZ, Jesús María, La expansión del Derecho penal, $2^{\mathrm{a}}$ ed., Civitas, Madrid, 2001.

SILVA SÁNCHEZ, Jesús María, "La teoría de la determinación de la pena como sistema (dogmático): un primer esbozo", InDret, 2/2007, pp. 1-15, en http://www.indret.com/pdf/426_es.pdf [visitado el 22.03.2018].

VAN WEEZEL, Alex, La garantía de tipicidad en la Jurisprudencia del Tribunal Constitucional, Santiago: Abeledo Perrot-Thomson Reuters, 2011.

VIGANO, Francesco, "Ne bis in idem e contrasto agli abusi di mercato: una sfida per il legislatore e i giudici italiani Riflessioni de lege lata e ferenda sull'impatto della sentenza Grande Stevens nell'ordinamento italiano", Diritto penale contemporaneo, $\mathrm{N}^{\mathrm{o}} 1$ (2016), pp. 186-202, en: https://www.penalecontemporaneo.it/foto/DPC_Riv_Trim_1_16.pdf\#page=195\&vie $\underline{\mathrm{w}=\text { fit }}$ [visitado el 22.08.2017]. 